\title{
Protein Tyrosine Nitration and Thiol Oxidation by Peroxynitrite-Strategies to Prevent These Oxidative Modifications
}

\author{
Andreas Daiber ${ }^{1, \dagger}{ }^{\dagger}$, Steffen Daub ${ }^{1, \dagger}$, Markus Bachschmid ${ }^{2}$, Stefan Schildknecht ${ }^{3}$, \\ Matthias Oelze ${ }^{1}$, Sebastian Steven ${ }^{1}$, Patrick Schmidt ${ }^{3}$, Alexandra Megner ${ }^{3}$, Masayuki Wada ${ }^{4}$, \\ Tadashi Tanabe ${ }^{4}$, Thomas Münzel ${ }^{1}$, Serge Bottari ${ }^{5}$ and Volker Ullrich ${ }^{3}$ \\ 1 2nd Medical Clinic, Molecular Cardiology, Medical Center of the Johannes Gutenberg University, \\ Mainz 55131, Germany; E-Mails: daub.steffen@googlemail.com (S.D.); \\ matzeoelze@aol.com (M.O.); sebastiansteven@gmx.de (S.S.); tmuenzel@uni-mainz.de (T.M.) \\ 2 Vascular Biology Section, Whitaker Cardiovascular Institute, Boston University Medical Center, \\ Boston, MA 02118, USA; E-Mail: markus.bachschmid@t-online.de \\ 3 Department of Biology, University of Konstanz, Konstanz 78457, Germany; \\ E-Mails: stefan.schildknecht@uni-konstanz.de (S.S.); Patrick.Schmidt@gmx.de (P.S.); \\ volker.ullrich@uni-konstanz.de (V.U.) \\ 4 Department of Pharmacology, National Cardiovascular Center Research Institute, Suita, \\ Osaka 565-8565, Japan; E-Mail: wada@jsc.ri.ncvc.go.jp \\ 5 Laboratory of Fundamental and Applied, Bioenergetics, INSERM U1055, Grenoble Universités \\ and Pôle de Biologie, CHU, Grenoble 38400, France; E-Mail: serge.bottari@ujf-grenoble.fr \\ $\dagger$ These authors contributed equally to this work. \\ * Author to whom correspondence should be addressed; E-Mail: andreas.daiber@bioredox.com; \\ Tel.: +49-6131-176-280, Fax: +49-6131-176-293.
}

Received: 31 December 2012; in revised form: 11 March 2013 / Accepted: 18 March 2013 / Published: 8 April 2013

\begin{abstract}
The reaction product of nitric oxide and superoxide, peroxynitrite, is a potent biological oxidant. The most important oxidative protein modifications described for peroxynitrite are cysteine-thiol oxidation and tyrosine nitration. We have previously demonstrated that intrinsic heme-thiolate (P450)-dependent enzymatic catalysis increases the nitration of tyrosine 430 in prostacyclin synthase and results in loss of activity which contributes to endothelial dysfunction. We here report the sensitive peroxynitrite-dependent nitration of an over-expressed and partially purified human
\end{abstract}


prostacyclin synthase $(3.3 \mu \mathrm{M})$ with an $\mathrm{EC}_{50}$ value of $5 \mu \mathrm{M}$. Microsomal thiols in these preparations effectively compete for peroxynitrite and block the nitration of other proteins up to $50 \mu \mathrm{M}$ peroxynitrite. Purified, recombinant PGIS showed a half-maximal nitration by $10 \mu \mathrm{M}$ 3-morpholino sydnonimine (Sin-1) which increased in the presence of bicarbonate, and was only marginally induced by freely diffusing $\mathrm{NO}_{2}$-radicals generated by a peroxidase/nitrite/hydrogen peroxide system. Based on these observations, we would like to emphasize that prostacyclin synthase is among the most efficiently and sensitively nitrated proteins investigated by us so far. In the second part of the study, we identified two classes of peroxynitrite scavengers, blocking either peroxynitrite anion-mediated thiol oxidations or phenol/tyrosine nitrations by free radical mechanisms. Dithiopurines and dithiopyrimidines were highly effective in inhibiting both reaction types which could make this class of compounds interesting therapeutic tools. In the present work, we highlighted the impact of experimental conditions on the outcome of peroxynitrite-mediated nitrations. The limitations identified in this work need to be considered in the assessment of experimental data involving peroxynitrite.

Keywords: nitric oxide; superoxide; peroxynitrite; protein tyrosine nitration; thiol oxidation; peroxynitrite scavengers; prostacyclin synthase

Abbreviations: PGIS, prostacyclin synthase; MnSOD, manganese superoxide dismutase; NOS, nitric oxide synthase; $\mathrm{P} 450_{\mathrm{BM}-3}$, cytochrome $\mathrm{P} 450$ bacterial monooxygenase-3; $\mathrm{P} 450_{\mathrm{CAM}}$, cytochrome P450 camphor-5-monooxygenase; Sin-1, 3-morpholino sydnonimine; BSA, bovine serum albumin; ADH, alcohol dehydrogenase; MP-11, microperoxidase.

\section{Introduction}

Nitric oxide $(\cdot \mathrm{NO}, \mathrm{EDRF})$, a potent vasodilator, is formed from arginine by NO synthases [1]. Under physiological conditions, endothelial NO synthase (NOS3) generates low steady-state ·NO levels, dilating the smooth muscle of the vasculature via activation of the soluble guanylyl cyclase [2]. Superoxide $\left(\mathrm{O}_{2} \cdot{ }^{-}\right)$, a toxic reactive oxygen species that easily reacts with metal-sulfur-clusters and causes oxidative damage via Fenton chemistry, is formed by NADPH oxidases, xanthine oxidase, uncoupled NOS3 and mitochondria [3,4]. Under physiological conditions, $\mathrm{O}_{2} \cdot{ }^{-}$steady state levels originating from these sources are efficiently kept low by the enzymatic and non-enzymatic antioxidant system of the cell. In aging or diseases such as inflammation, hypertension, and atherosclerosis, $\mathrm{O}_{2}{ }^{-}$formation increases dramatically and at the same time inducible NO synthase (NOS2) generates high concentrations of $\cdot \mathrm{NO}$. Both radicals react in a diffusion-controlled fashion to yield the toxic and highly reactive nitrogen species peroxynitrite $\left(\mathrm{ONOO}^{-}\right)$[5], which has been shown to oxidize various biomolecules including proteins, DNA, lipids, as well as low molecular weight antioxidants [6]. The most prominent protein modifications mediated by peroxynitrite are the nitration and dimerization of tyrosine residues, the oxidation of cysteine thiol-groups, as well as the oxidation of methionine sulfur-groups [7,8]. Moreover, disruption of metal-sulfur-clusters has been demonstrated to 
result in oxidative inactivation of enzymatic catalysis. These oxidative modifications by $\mathrm{ONOO}^{-}$may modulate or inhibit enzymatic activity [9]. However, since $\mathrm{ONOO}^{-}$has been shown to contribute to pathophysiological conditions in various cardiovascular, neurodegenerative and inflammatory diseases [10-13], the majority of $\mathrm{ONOO}^{-}$-mediated oxidations obviously must have functional consequences that result in interference with cellular redox-signaling, cell damage, or in death of the entire organism [14]. In the following sections we will have a closer look at the protein tyrosine nitration.

Diverging reports on protein tyrosine nitration exist, with respect to specificity of detection methods, mechanisms of nitrotyrosine formation and pathophysiological or physiological significance [15-17], in particular in diseases related to oxidative stress [10,18-21]. For example, the nitration and modulation of activity of ERK1/2 and Akt play an important role in angiotensin-II triggered vascular complications [22,23]. Commonly used antibodies for semi-quantitative detection of 3-nitrotyrosine in tissues offer a great sensitivity but exert also an epitope preference, which leads to underestimation and misinterpretation of protein nitration. In contrast, total hydrolysis and subsequent HPLC-analysis offers a method for quantification of 3-nitrotyrosine [24,25]. Pitfalls in hydrolysis include losses of 3-nitrotyrosine by partially reducing conditions and false positive results due to the presence of nitrite and its nitrosating/nitrating properties under acidic conditions. Therefore, pronase digestion has been recommended [25,26].

The mechanism of Tyr-nitration was first found to proceed via peroxynitrite on a free radical based mechanism [24,27] but it turned out that heme-containing proteins facilitated this reaction by the formation of ferryl intermediates [25,28]. Prostacyclin synthase (PGIS) was proven sensitive to nitration by peroxynitrite which could be efficiently prevented by an inhibitory substrate analogue [29]. This suggested that tyrosine-nitration was a metal catalyzed process in close proximity to the active heme-iron site [29,30].

Considering the importance of prostacyclin as a vasodilator in the vasculature and heart [31], this oxidative inhibition of the enzyme suggested that it might be of high importance for physiology and pathophysiology. Using other $\mathrm{P} 450$ proteins as models, $\mathrm{P} 450_{\mathrm{NOR}}, \mathrm{P} 450_{\mathrm{BM}-3}$ and $\mathrm{P} 450_{\mathrm{CAM}}$, we were able to identify compound II $\left(\mathrm{FeO}^{\mathrm{IV}}\right)$ of the heme moiety as an essential intermediate of the catalysis of intrinsic tyrosine nitration or peroxynitrite degradation by P450 enzymes [32-34]. Although metal-catalyzed tyrosine nitration represents a major pathway of peroxynitrite-mediated nitration of specific protein tyrosine residues $[9,33,34]$, it should be noted that also carbon dioxide catalysis (with nitroso-peroxocarbonate as an intermediate) [35-37] and conversion of tyrosine to the more reactive tyrosinate residues in the neighborhood of Asp and Glu residues [38] play an important role for the physiological occurrence of this oxidative protein modification [9]. It is also important to note that not all metal-containing enzymes are nitrated in a similar autocatalytic fashion as observed for PGIS, $\mathrm{P} 450_{\mathrm{BM}-3}$ and $\mathrm{P} 450_{\mathrm{CAM}}$. For example $\mathrm{P} 450_{\mathrm{NOR}}$ and chloroperoxidase as well as hemoglobin rather catalyze the decomposition of peroxynitrite without significant nitration of the protein $[32,33,39,40]$.

Concerning the biological significance, PGIS activity was attenuated after nitration of Tyr430 by peroxynitrite [41] which contributed to endothelial dysfunction [42]. Another prominent target of peroxynitrite-dependent inhibition is manganese superoxide dismutase (MnSOD), the mitochondrial isoform of SOD. Although inhibition of this enzyme was not only associated with Tyr34 nitration, but 
could also involve dityrosine formation $[43,44]$, it has been demonstrated that reaction with peroxynitrite is catalyzed by the manganese cation [45].

One of the major caveats of assigning biological responses to tyrosine nitration, is the occurrence of other peroxynitrite-mediated posttranslational modifications which include thiol oxidation [46-48], sulfoxidations of methionine [49,50] and dityrosine formation [51,52], which can also lead to enzyme inhibition. Moreover, protein Tyr nitration might also leave the enzyme activity entirely unaffected. Therefore, various protein nitrations observed in models of endotoxemia or inflammation may only partially be connected to pathophysiological alterations [53,54]. Such conditions have been referred to as "nitrosative" stress, although different conditions for either nitration and nitrosation were required $[26,48]$ and might hence reflect diverse pathological states and situations. Nevertheless, nitration and nitrosation are both dependent on enhanced production of $\cdot \mathrm{NO}$ by NOS1 or NOS2. Regarding the nitration of endothelial PGIS, this can even involve only NOS3 and hence its mechanism of nitration rather reflects a mechanism of redox regulation than a consequence of oxidative stress [55].

With respect to the aforementioned literature, it could be of clinical importance to develop highly specific peroxynitrite scavengers in order to block peroxynitrite-mediated nitration and thiol oxidation. According to these chemical reactions-nitration proceeds via one-electron steps whereas thiol oxidation may involve one- as well as two-electron oxidation steps-the chemical properties of the scavenger groups will probably differ largely. A prominent member of one-electron scavengers is uric acid which reacts with peroxynitrite-derived free radicals $[56,57]$ whereas ebselen is probably the most potent synthetic scavenger of peroxynitrite anion and hence inhibitor of two-electron oxidations [58,59].

In the present study we revisited PGIS and $\mathrm{P} 450_{\mathrm{BM}-3}$ as models of heme-thiolate catalyzed tyrosine nitration, with special emphasis on how these nitrations might be inhibited. In addition, we also investigated the inhibition of nitration and thiol oxidation reactions by various compounds using models for these oxidative modifications: inactivation of alcohol dehydrogenase by thiol oxidation at the active site, as well as peroxynitrite-mediated nitration of phenol or bovine serum albumin.

\section{Results}

\subsection{Tyrosine Nitration of PGIS}

Human PGIS was overexpressed in Spodoptera frugiperda 21 (Sf21) cells and enriched microsomal fractions, offering a sufficient degree of purity, were used to study peroxynitrite mediated PGIS nitration Bolus added peroxynitrite and Sin-1 [60] caused a concentration-dependent nitration of PGIS, starting at concentrations as low as 2.5 and $10 \mu \mathrm{M}$, respectively (Figures 1 and S1). Even in untreated samples, a slight staining was observed due to nitration artifacts during the preparation of microsomes. Protein loading was controlled by Ponceau S staining and by a polyclonal PGIS-antibody (Figure 1A). Slight differences in sample loading were observed and paralleled to small variations in detected nitrotyrosine. Quantitative HPLC analysis of 3-nitrotyrosine from pronase digested microsomal PGIS perfectly matched up with the Western blot. Bolus treatment with peroxynitrite revealed that a 3-fold molar excess of peroxynitrite already caused nitration of a single tyrosine per PGIS molecule $(10 \mu \mathrm{M}$, see Figure 1C). Saturation of nitration was observed at 50-100 $\mu \mathrm{M}$ peroxynitrite and corresponded to two nitrotyrosine molecules per protein (not shown). 
Figure 1. Detection and quantification of tyrosine nitration in human prostacyclin synthase (PGIS). (A) Western blot analysis of microsomal fractions (1 $\mathrm{mg} / \mathrm{mL}$ total protein) containing $200 \mu \mathrm{g} / \mathrm{mg}$ PGIS which were treated with increasing amounts of authentic peroxynitrite $(\mathrm{PN}, 0-50 \mu \mathrm{M})$ or $(\mathbf{B})$ Sin-1 $(0-100 \mu \mathrm{M})$. The figures show staining with Ponceau S, with a polyclonal anti-PGIS antibody and with a monoclonal anti-3-nitrotyrosine antibody; (C) HPLC-based quantification of 3-nitrotyrosine in microsomal fractions $(1 \mathrm{mg} / \mathrm{mL})$ containing $200 \mu \mathrm{g} / \mathrm{mg}$ PGIS which were treated with increasing amounts of authentic peroxynitrite $(\mathrm{PN}, 0-20 \mu \mathrm{M})$ or peroxynitrite generated in situ by Sin-1 $(10-100 \mu \mathrm{M})$. Data are means \pm SEM $(\mathbf{C})$ or representative of three independent experiments (A and $\mathbf{B})$.
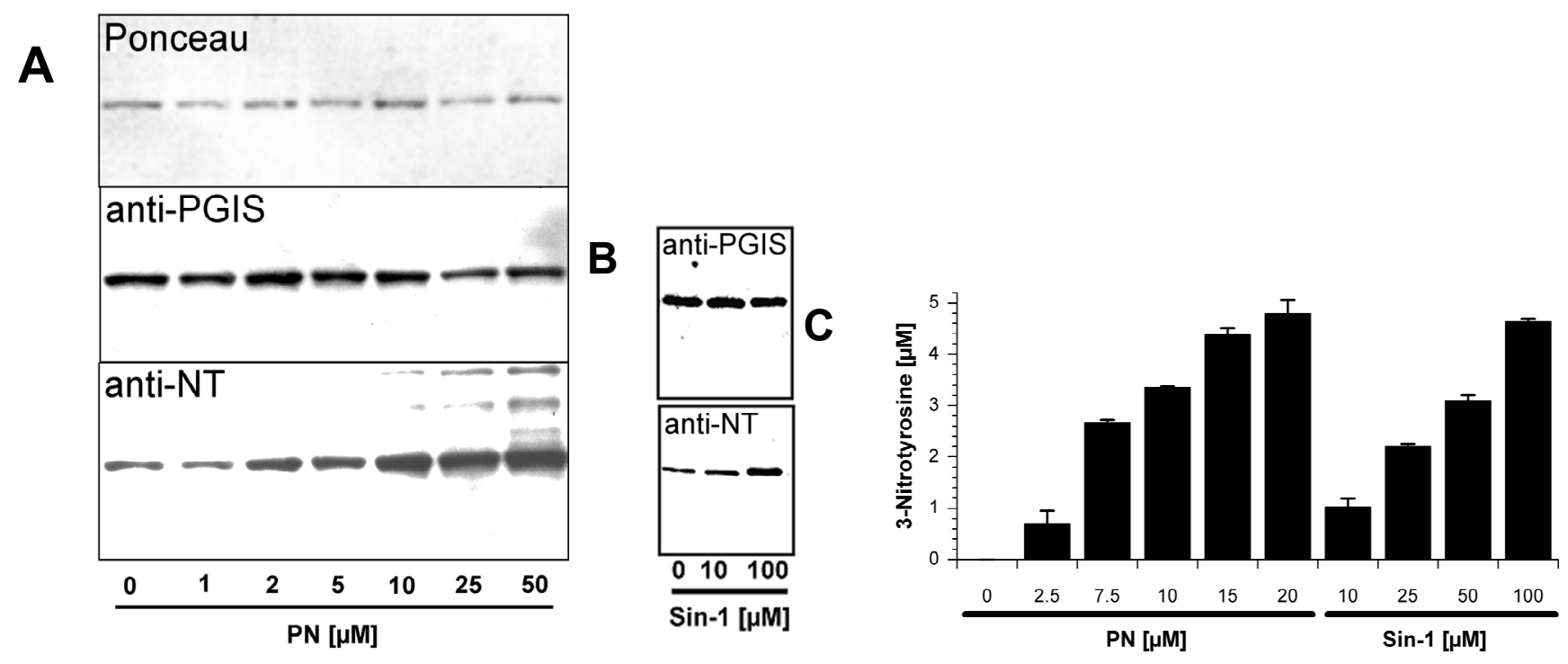

Higher concentrations of $\operatorname{Sin}-1 \quad(50 \mu \mathrm{M}$ roughly equals a steady state release of peroxynitrite - in the range of $50 \mathrm{nM} / \mathrm{s}$; Figure 1C) were required to achieve full nitration of a single Tyr/PGIS molecule and saturation occurred at $500 \mu \mathrm{M}$ and corresponded to $1.8 \mathrm{~mol}$ of 3-nitrotyrosine per mol of PGIS (not shown). Noteworthy is that nitration of purified bovine hemoglobin required at least $250 \mu \mathrm{M}$ peroxynitrite to become detectable by Western blot (Figure 2).

These results confirm the high reactivity of PGIS towards peroxynitrite due to heme-thiolate catalysis and support our previous findings that the nitrated enzyme is already present in isolated tissue- and cell-fractions. However, this may also indicate some background or cross-reactivity of the nitrotyrosine antibodies used (since HPLC analysis revealed no nitration in the control samples, Figure 1C) and demonstrated the limitations of qualitative detection of nitrated proteins by these antibodies. 
Figure 2. Detection and quantification of tyrosine nitration in bovine hemoglobin $(\mathrm{Hb})$. Western blot analysis of purified $\mathrm{Hb}(20 \mu \mathrm{M})$ treated with increasing amounts of authentic peroxynitrite $(\mathrm{PN}, 0-2000 \mu \mathrm{M})$ or nitronium tetrafluoroborate $(5 \mathrm{mM})$. The figure shows the hybridization with a monoclonal anti-3-nitrotyrosine antibody. Stained bands correspond to the $\alpha$ - and/or $\beta$-subunits at $16 \mathrm{kDa}$ as well as to their dimers at around $30 \mathrm{kDa}$. For corresponding pronase digestion data see Figure $\mathrm{S} 2$ in supplementary information.

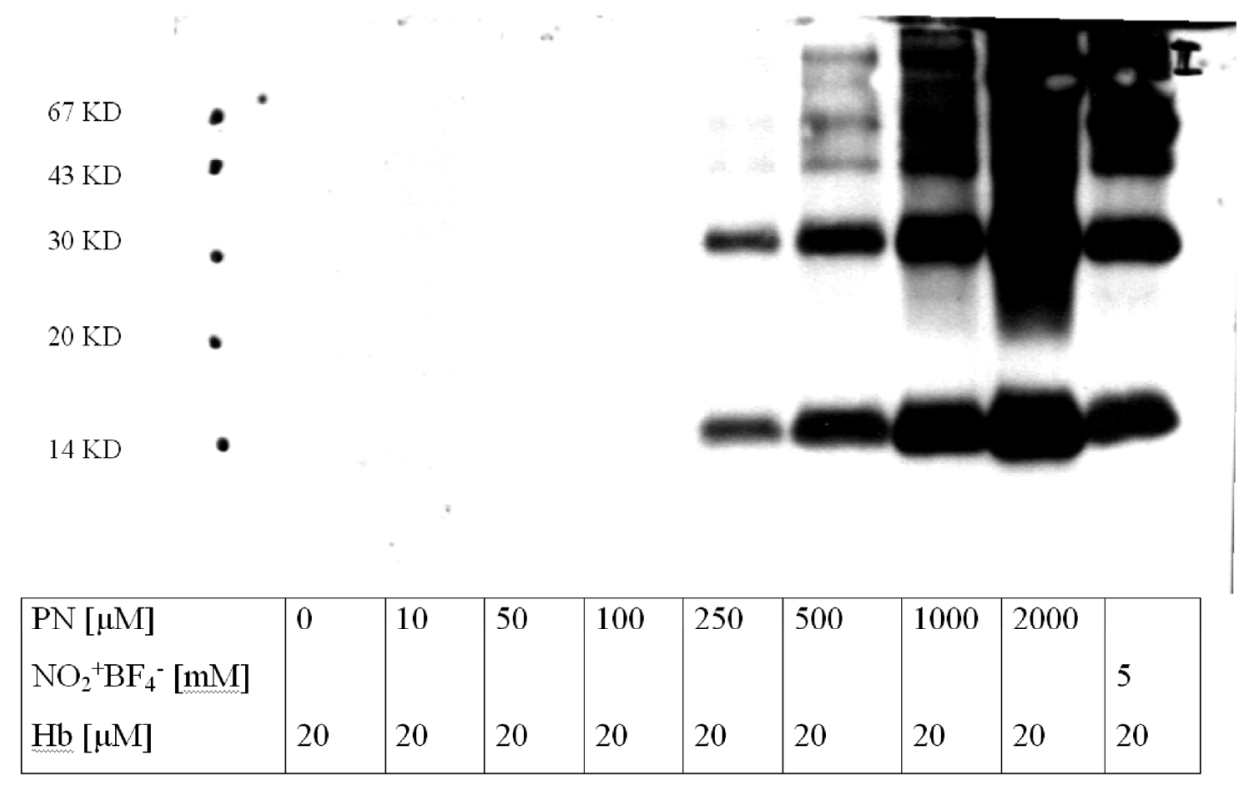

The sensitivity of microsomal PGIS preparations towards nitration was always significantly lower than that of purified PGIS (reported $\mathrm{IC}_{50}$ values $\approx 500 \mathrm{nM} v s . \approx 50 \mathrm{nM}$ ). The microsomal "quenching effect" towards nitration was demonstrated by treating bovine serum albumin $(5 \mu \mathrm{M})$ either in the absence or presence of bovine coronary artery microsomes with peroxynitrite (Figure 3A). Addition of microsomes required about 5-fold higher concentrations of peroxynitrite to cause a similar degree of nitration than for pure albumin. Since microsomal concentration of endogenous PGIS is negligible compared to the amount of albumin (see Ponceau S staining in Figure S3, supplementary information), nitrated PGIS was below the detection limit of Western blots. These results are in perfect agreement with the results obtained by pronase digestion and quantitative HPLC analysis of nitrotyrosine (Figure 3B).

Peroxynitrite has been shown to efficiently react with sulfhydryl groups. To prove the contribution of free protein thiol groups to the antioxidant potential of microsomal suspensions, sulfhydryls were blocked by Ellman's reagent (DTNB). In these preparations, peroxynitrite-mediated nitration of PGIS and other proteins was significantly increased, indicating that protein bound thiol groups can efficiently scavenge peroxynitrite (Figure 3C). 
Figure 3. Effects of bovine aortic microsomes on the nitration of bovine serum albumin (BSA) and of Ellman's reagent on the nitration of PGIS and other proteins by peroxynitrite. (A) Detection of 3-nitrotyrosine in BSA by Western blot analysis using a monoclonal anti-3-nitrotyrosine antibody. BSA $(5 \mu \mathrm{M})$ was incubated with authentic peroxynitrite (PN, 0-250 $\mu \mathrm{M})$ in the presence or absence of bovine aortic microsomes (1 $\mathrm{mg} / \mathrm{mL}$ total protein); (B) HPLC analysis of free 3-nitrotyrosine content in pronase digests from samples used for Western blot; (C) Detection of 3-nitrotyrosine positive proteins in bovine aortic microsomes by Western blot analysis using a monoclonal anti-3-nitrotyrosine antibody. Bovine aortic microsomes $(1 \mathrm{mg} / \mathrm{mL}$ total protein), which were either treated or not with the sulfhydryl oxidizing Ellman's reagent (DTNB) were mixed with authentic peroxynitrite $(\mathrm{PN}, 0-100 \mu \mathrm{M})$. Data are representative of two independent experiments.

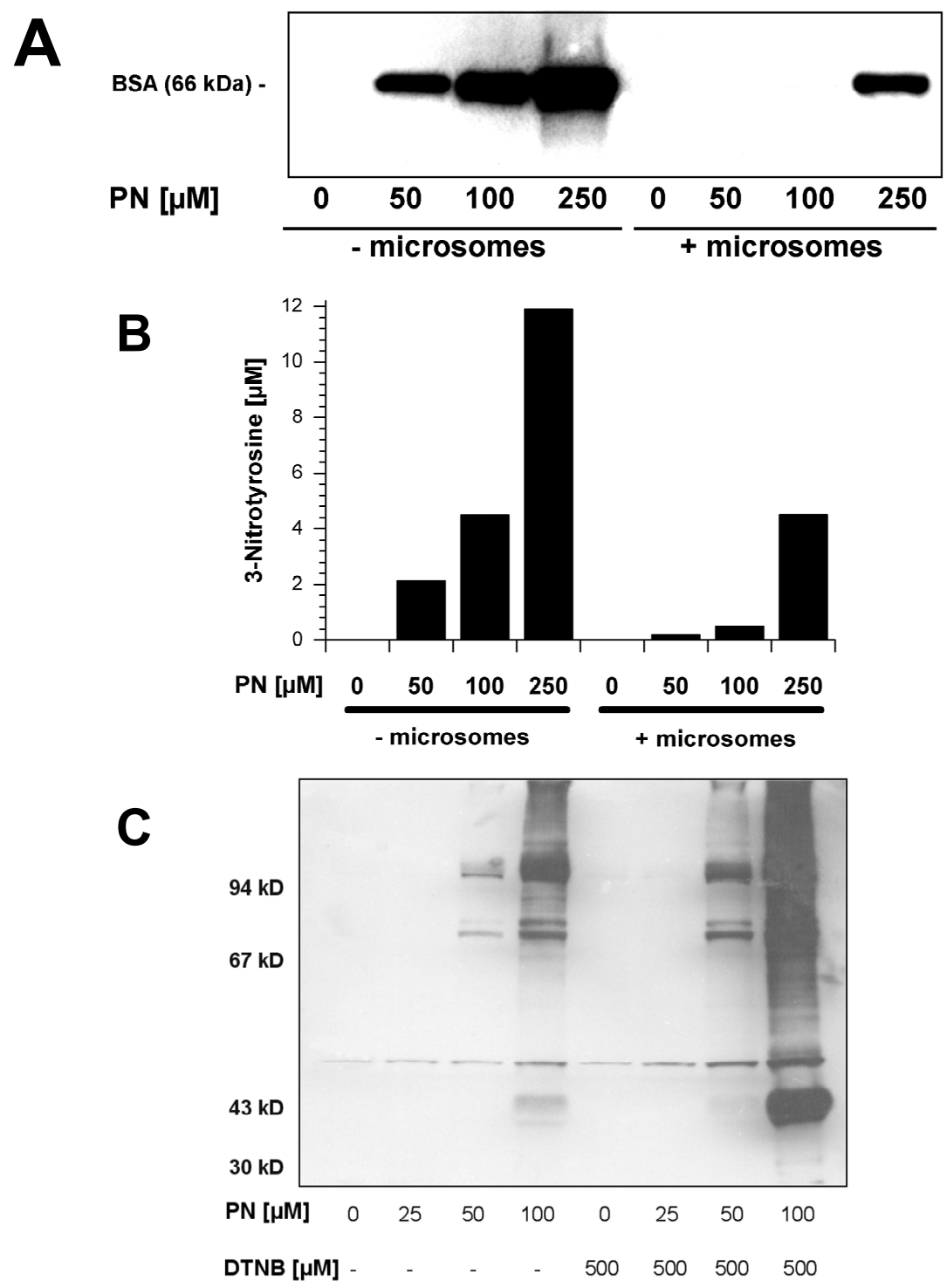

Using purified recombinant PGIS, we were able to determine half-maximal nitration by peroxynitrite generated in situ from Sin-1 $(10 \mu \mathrm{M}$, Figure 4A) which was increased by bicarbonate in a concentration-dependent fashion, indicating a role of carbon dioxide for the nitration process of PGIS 
(Figure 4B). In contrast, free iron(II)/copper(II) ions and polyethylene glycolated $\mathrm{Cu}, \mathrm{Zn}$-superoxide dismutase (PEG-SOD) completely abolished the nitration of PGIS. Peroxidase-catalyzed nitrogen dioxide radical formation (even at higher concentrations of nitrite and hydrogen peroxide) only caused marginal nitration levels of the purified enzyme (Figure 4B). Decomposed Sin-1 yielded only background 3-nitrostyrosine staining, which showed no appreciable increase in the presence of bicarbonate (Figure 4C). In contrast, PGIS nitration was increased by fresh Sin-1 (10 $\mu \mathrm{M})$ and was blocked by almost $40 \%$ in the presence of the active site inhibitor of PGIS, U-51605. Bicarbonate caused a minor increase in the nitration signal, indicating that the nitrosoperoxycarbonate $\left(\mathrm{ONOOCO}_{2}{ }^{-}\right)$species also required access to the heme-thiolate active site of PGIS in order to mediate efficient nitration of the enzyme (Figure 4C).

Figure 4. Nitration of purified, recombinant PGIS by in situ generated peroxynitrite. (A) Detection of 3-nitrotyrosine in PGIS by Western blot analysis using a polyclonal amti-PGIS antibody and a monoclonal anti-3-nitrotyrosine antibody. PGIS (300 nM) was treated with peroxynitrite generated in situ from Sin-1 (5 and $20 \mu \mathrm{M})$. Data are representative of two independent experiments; (B) Detection of 3-nitrotyrosine in PGIS by dot blot analysis using a monoclonal anti-3-nitrotyrosine antibody. PGIS (80 nM) was not treated (lane 1) or treated with peroxynitrite generated in situ from Sin-1 (10 $\mu \mathrm{M})$ (lane 2) in the absence or presence of $1 \mathrm{mM}$ (lane 3) or $10 \mathrm{mM}$ (lane 4) bicarbonate or $50 \mu \mathrm{M}$ iron(II) plus copper (II) ions (lane 5) or $100 \mathrm{U} / \mathrm{mL}$ PEG-SOD (lane 6). PGIS was also incubated with $0.1 \mu \mathrm{M}$ horseradish peroxidase (HRP) plus $10 \mu \mathrm{M}$ nitrite/hydrogen peroxide (lane 7) or plus $100 \mu \mathrm{M}$ nitrite/hydrogen peroxide (lane 8); (C) Detection of 3-nitrotyrosine in PGIS by dot blot analysis using a monoclonal anti-3-nitrotyrosine antibody. PGIS (80 $\mathrm{nM}$ ) was treated with $10 \mu \mathrm{M}$ decomposed Sin-1, from a $1 \mathrm{mM}$ Sin-1 solution in $1 \mathrm{M}$ potassium phosphate buffer $\mathrm{pH} 7.4$ incubated for $90 \mathrm{~min}$ at $37^{\circ} \mathrm{C}$, in the absence (lane 9) or presence of $10 \mathrm{mM}$ bicarbonate (lane 10), freshly prepared $10 \mu \mathrm{M}$ Sin-1 in the absence (lane 11) or presence of $2 \mu \mathrm{M}$ U-51605 (lane 12) as well as $2 \mu \mathrm{M}$ U-51605 plus $10 \mathrm{mM}$ bicarbonate (lane 13). All incubations were performed in $0.1 \mathrm{M}$ potassium phosphate buffer $\mathrm{pH} 7.4$ at $37{ }^{\circ} \mathrm{C}$ for $90 \mathrm{~min}$. Data are means $\pm \mathrm{SEM}$ of three independent experiments.

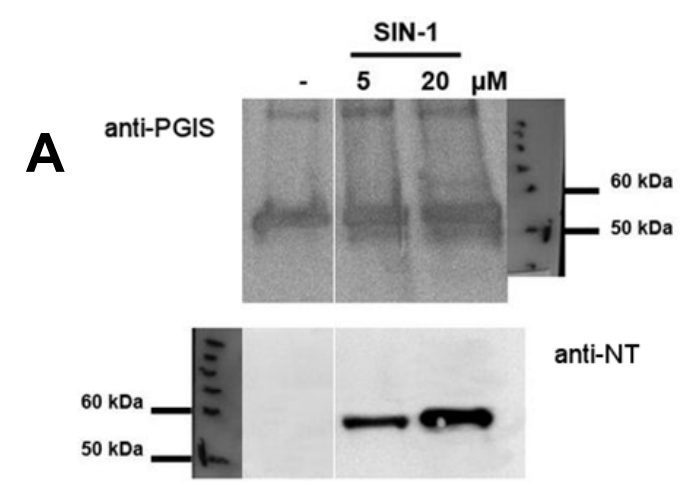


Figure 4. Cont.
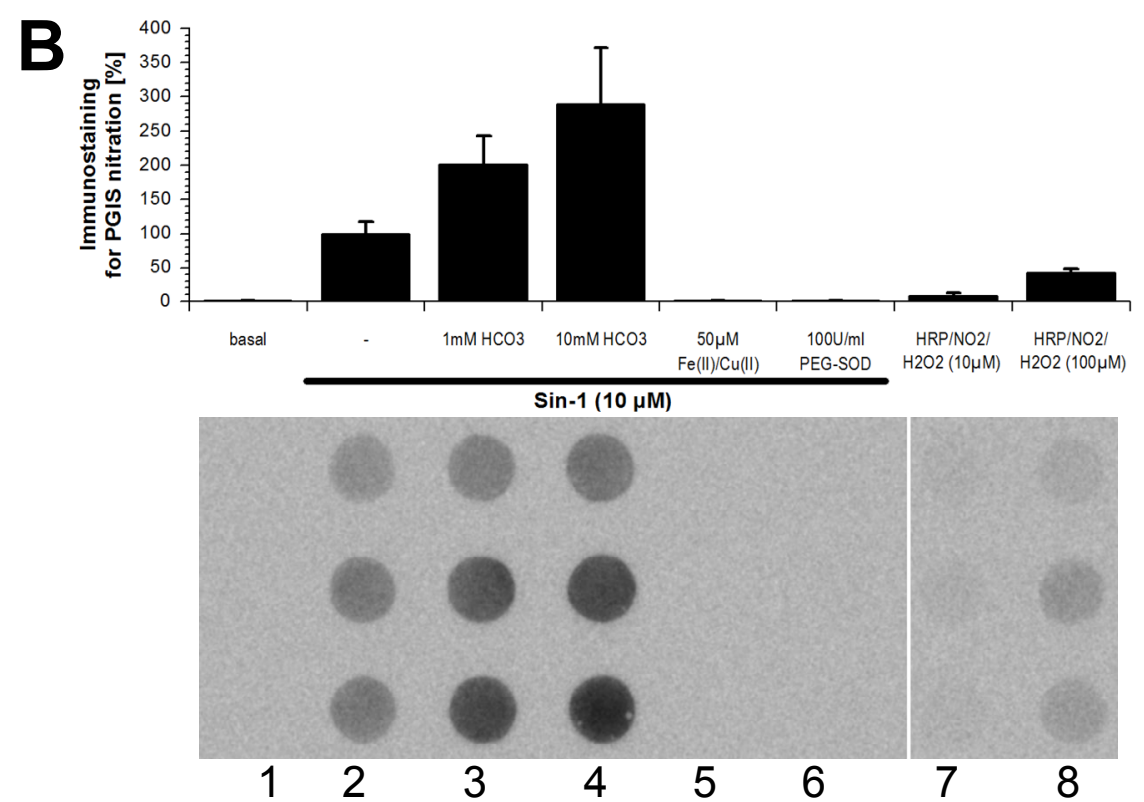

C

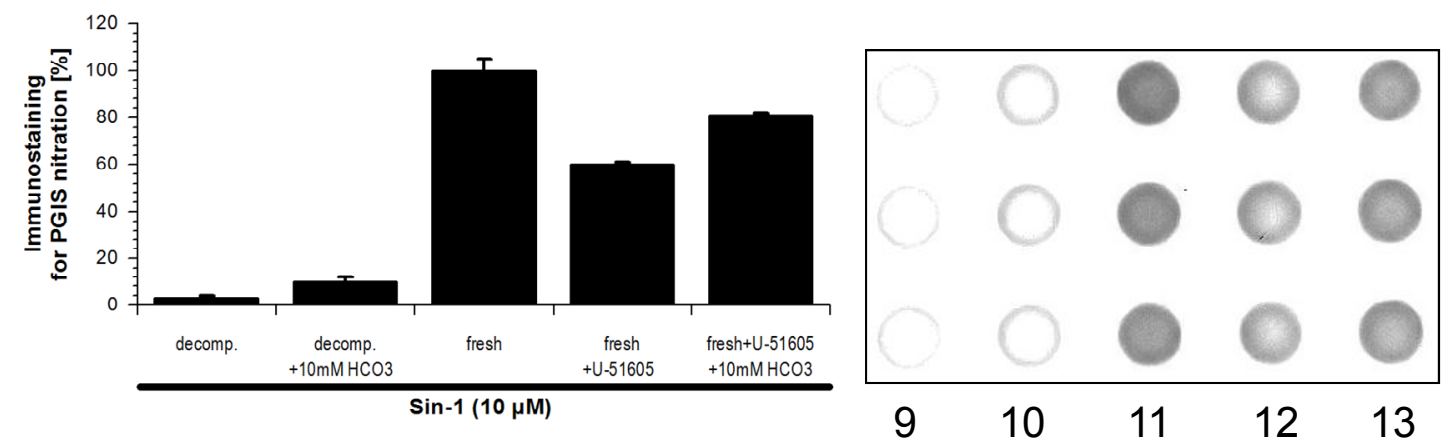

Regarding the biological importance of PGIS nitration and activity as well as the known nitration site at Tyr430, future effort should be focused on the identification of a specific marker, such as a nitrated peptide, of inactivated PGIS. As reported before [41], thermolysine digestion yielded the unusual fragment $\mathrm{NH}_{2}-\mathrm{LKNY}\left(\mathrm{NO}_{2}\right)-\mathrm{OH}$ and could be detected by $\mathrm{MS}$ at $291.6 \mathrm{~m} / \mathrm{z}$, indicating that the nitro group introduced an additional thermolysine cleavage site (supplementary Figure S4). Detailed information on stability and implications of nitrated PGIS peptide is provided in supplementary information (supplemental Section 1.2).

\subsection{Nitration of $\mathrm{P} 4 \mathrm{O}_{\mathrm{BM}-3}$ by in Situ Generated Peroxynitrite from Sin-1 or Xanthine} Oxidase/Spermine NONOate

Nitration of P450 $0_{\mathrm{BM}-3}$ enzymes (wild type and F87Y mutant) and the molecular mechanisms involved were previously investigated $[26,33]$. The $\mathrm{P} 450_{\mathrm{BM}-3} \mathrm{~F} 87 \mathrm{Y}$ mutant has a higher sensitivity towards nitration since the introduced tyrosine is located close to the active site. Both in situ nitration systems (XO/NONOate or Sin-1) efficiently nitrated the enzyme whereas only a minor effect was observed when the enzyme was incubated with the NO-donor alone (Figure 5A). Superoxide dismutase nearly entirely blocked XO/NONOate and Sin-1-induced nitration (Figure 5A). Detailed information is provided in the supplementary information (supplemental section 1.1 and 
Figures S5 and S6). Nitration was inhibited by co-incubation of the enzyme with its endogenous substrate palmitate, which reduces the accessibility to the active site to peroxynitrite (Figure 5B,C). These results are in agreement with the previous finding that tyrosine nitration depends on heme-thiolate catalysis. Furthermore, the nitration of P450 $0_{\mathrm{BM}-3}$ F87Y mutant by Sin-1 could be efficiently prevented by addition of glutathione and with a lower efficacy by phenol, or ascorbate whereas bicarbonate significantly increased nitration (Figure 5D). Nitration was most efficiently suppressed by a system consisting of horseradish peroxidase and phenol, glutathione or ascorbate (not shown). This system was described as a highly efficient sink for peroxynitrite [61] although it might also be pro-oxidative [62]. Previous studies [26] and additional Western blot analysis demonstrated that bolus additions of peroxynitrite $(500 \mu \mathrm{M})$ nitrated various proteins indistinctively with only minor differences in nitration sensitivity (Figure S7 in supplementary information). In contrast, peroxynitrite generated in situ from Sin-1 $(250$ or $500 \mu \mathrm{M})$ led to selective nitration of only certain proteins, clearly indicating the dependence on metal-catalysis in conjunction with vicinal tyrosine residues (Figure S7 in supplementary information).

Figure 5. Effect of palmitate on the nitration of purified wildtype and F87Y variant $\mathrm{P} 450_{\mathrm{BM}-3}$ by in situ generated peroxynitrite. (A) Detection of 3-nitrotyrosine in $\mathrm{P} 450_{\mathrm{BM}-3}$ F87Y variant by Western blot analysis using monoclonal and polyclonal anti-3-nitrotyrosine antibodies. P450 ${ }_{\mathrm{BM}-3} \mathrm{~F} 87 \mathrm{Y}$ variant $(2 \mu \mathrm{M})$ was treated with peroxynitrite generated in situ using xanthine oxidase (XO, $2.8 \mathrm{mU} / \mathrm{mL})$ and spermine NONOate $(100 \mu \mathrm{M})$ in the presence or absence of $\mathrm{Cu}, \mathrm{Zn}$-SOD and $(\mathbf{B})$ in the presence of increasing amounts of palmitate $(0-250 \mu \mathrm{M})$; (C) Detection of 3-nitrotyrosine in $\mathrm{P} 450_{\mathrm{BM}-3}$ by Western blot analysis using monoclonal and polyclonal anti-3-nitrotyrosine antibodies. P450 ${ }_{\mathrm{BM}-3}$ was treated with peroxynitrite generated in situ using Sin-1 $(100 \mu \mathrm{M})$ in the presence of increasing palmitate concentrations (50-200 $\mu \mathrm{M})$; (D) Effect of antioxidants and bicarbonate on the nitration of $\mathrm{P} 450_{\mathrm{BM}-3} \mathrm{~F} 87 \mathrm{Y}$ variant by in situ generated peroxynitrite. Detection of 3-nitrotyrosine in $\mathrm{P} 450_{\mathrm{BM}-3} \mathrm{~F} 87 \mathrm{Y}$ variant by Western blot analysis using a monoclonal anti-3-nitrotyrosine antibody. $\mathrm{P} 450_{\mathrm{BM}-3} \mathrm{~F} 87 \mathrm{Y}$ variant $(0.5 \mu \mathrm{M})$ was treated with peroxynitrite generated in situ using Sin-1 $(100 \mu \mathrm{M})$ in the absence or presence of glutathione (GSH), ascorbate (Asc), phenol (Phe) or bicarbonate. HX means hypoxanthine. Data are representative of two independent experiments.

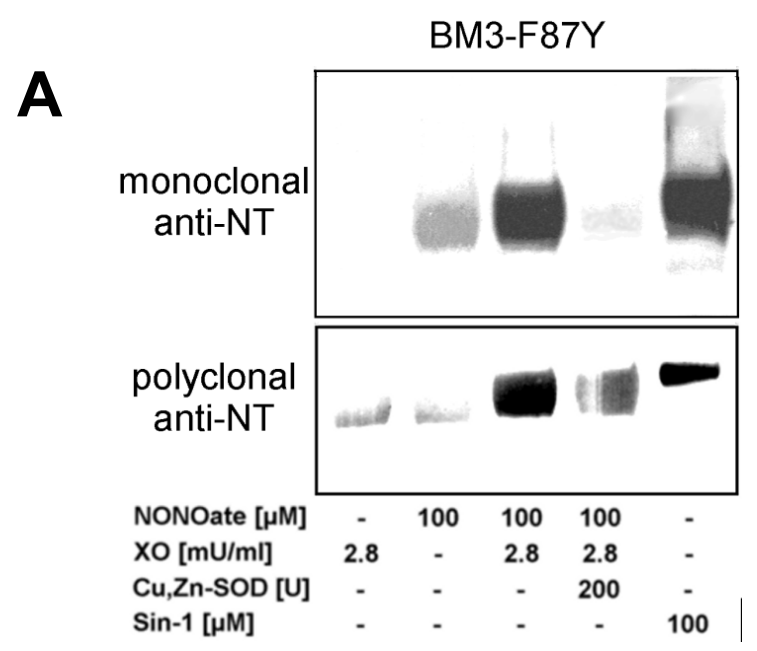


Figure 5. Cont.
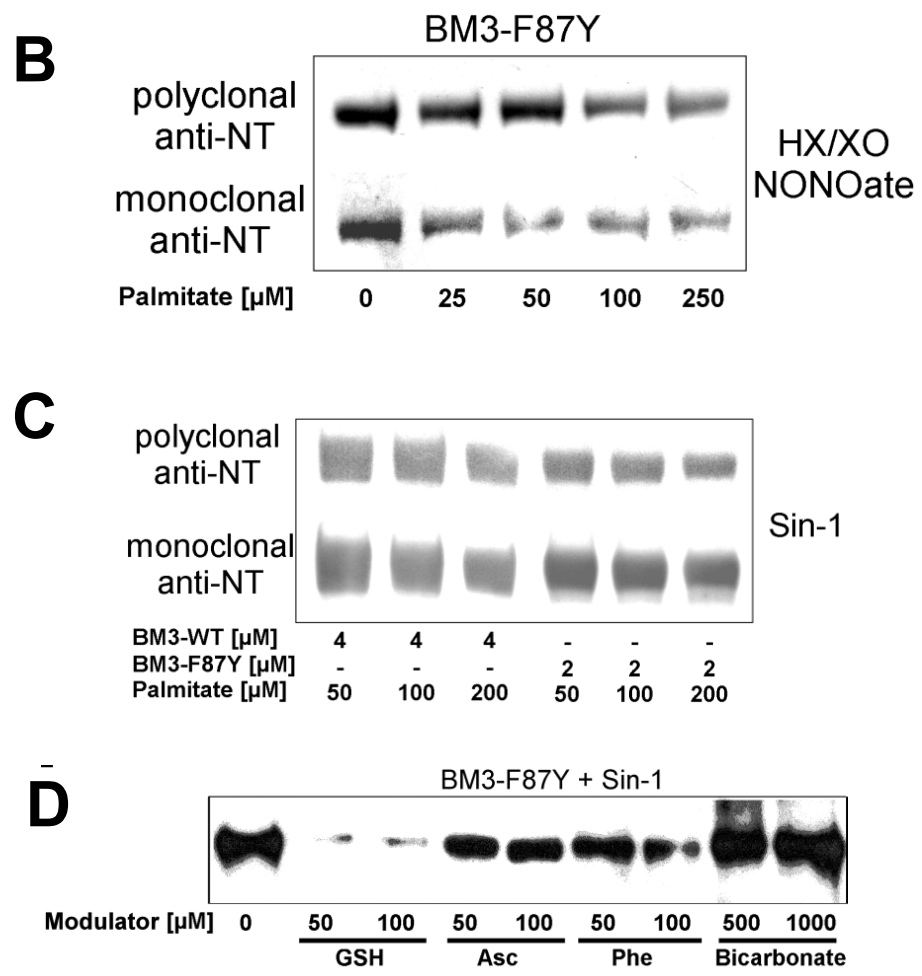

\subsection{Scavengers of Peroxynitrite Inhibiting the Nitration and Hydroxylation of Phenol}

Phenol was used instead of tyrosine since its solubility is superior in aqueous solutions and the availability of the para-position (with regard to the hydroxyl group) allowed us to study the nitrosative reactivity of peroxynitrite through the formation of the stable 4-nitrosophenol product (3-nitrosotyrosine is unstable). Moreover, the standards of reaction products are commercially available and the reaction mechanism of phenol with peroxynitrite is even better characterized than that of tyrosine. Finally, phenol nitration has proven to be a valid model for protein tyrosine nitration. Peroxynitrite-mediated phenol nitration has been reported to involve phenoxy radicals [63] and can be considered as two subsequent single-electron oxidation steps conducted by peroxynitrous acid (ONOOH), or more precisely the caged radical of decaying peroxynitrite $[24,52,64,65]$. The inhibition of nitrophenol formation at $\mathrm{pH} 6.0$ in the peroxynitrite/phenol system was assessed in the presence of several peroxynitrite-scavengers at various concentrations. Two major categories of inhibitors emerged: the first one showed an exponential concentration-dependency (uric acid derivatives, dithio-purine and -pyrimidine), whereas the second one followed a more linear concentration-dependency (thiols, ebselen, methionine, tyrosine and ascorbate) (Figure S8 in supplementary information). This behavior is directly related to their reactivity towards $\mathrm{ONOOH}$-derived free radicals or $\mathrm{ONOO}^{-}$. Table 1 shows the $\mathrm{IC}_{50}$-values of some natural antioxidants and synthetic counterparts for phenol nitration by peroxynitrite. It turned out, that among the best inhibitors of phenol nitration are uric acid and its 1,3- and 3,7-dimethyl analogues (DMUA), whereas Se-methionine and methionine itself showed low scavenging efficacy in this system. Interestingly, xanthine, allopurinol, caffeine, allantoin and alloxan, which are all structurally related to uric acid, were without any effect in accordance with a previous report [66]. 
Table 1. Half-maximal inhibition concentrations ( $\mathrm{IC}_{50}$-values) of various compounds for the nitration $(\mathrm{pH} 6)$ and nitrosation $(\mathrm{pH}$ 9) of phenol by peroxynitrite *

\begin{tabular}{cccc}
\hline Scavenger & $\mathbf{I C}_{\mathbf{5 0}}(\boldsymbol{\mu M})$ & Scavenger & $\mathbf{I C}_{\mathbf{5 0}}(\boldsymbol{\mu M})$ \\
\hline Glutathione & $181 \pm 20 / 380 \pm 57$ & Methionine & $450 \pm 34 / 690 \pm 75$ \\
Ascorbate & $88 \pm 18 / 133 \pm 18$ & Uric acid & $40 \pm 10 / 57 \pm 8$ \\
2,6-Dithiopurine & $35 \pm 13 / 36 \pm 14$ & 2,6-Dithiopyrimidine & $32 \pm 4 / 43.5 \pm 9.5$ \\
Ebselen & $128 \pm 5 / 190 \pm 11$ & 1,3-Dimethyluric acid & $36.5 \pm 1.5 / 25 \pm 12$ \\
Se-methionine & $250 \pm 13 / 170 \pm 28$ & Xanthine & $>1 \mathrm{mM} />1 \mathrm{mM}$ \\
Cysteine & $64 \pm 14 / 425 \pm 125$ & 3,9-Dimethyluric acid & $141 \pm 7 / \mathrm{n} . \mathrm{d}$. \\
Alloxan & $>1 \mathrm{mM} / \mathrm{n} . \mathrm{d}$. & 3,7-Dimethyluric acid & $19 \pm 3 / \mathrm{n} . \mathrm{d}$. \\
2-Thiobarbituric acid & $37 \pm 6 / 26 \pm 4$ & Allopurinol & $>1 \mathrm{mM} />1 \mathrm{mM}$ \\
Caffeine & $>1 \mathrm{mM} / \mathrm{n} . \mathrm{d}$. & Allantoin & $>1 \mathrm{mM} / \mathrm{n} . \mathrm{d}$. \\
\hline
\end{tabular}

* First value for nitration ( $\mathrm{pH} 6$ ), second value for nitrosation $(\mathrm{pH} \mathrm{9).} 5 \mathrm{mM}$ phenol were reacted with $655 \mu \mathrm{M}$ peroxynitrite at $\mathrm{pH} 6$ and $400 \mu \mathrm{M}$ peroxynitrite at $\mathrm{pH}$ 9. n.d. means not determined.

In a different set of experiments, constant concentrations of peroxynitrite, phenol and scavengers were used to measure the hydroxylation of phenol by peroxynitrite (Figure S9 in supplementary information). Again, uric acid was the most effective in suppressing hydroxy-products and benzoquinone. Ascorbate, GSH, cysteine, ebselen and methionine showed only minor effects on hydroxylation. In the case of 2,6-DTPu and -DTPy, hydroxy-products and benzoquinone could not be detected by HPLC due to interfering product peaks. Additional experiments demonstrated no significant effects on peroxynitrite-mediated hydroxylation or nitration by phosphoenolpyruvate, oxalate, acetone or $\alpha$-ketoglutarate, but a small decrease in nitration by acetaldehyde and a trialkyl-phosphine (not shown). Pyruvate showed a minor increase in nitration (not shown). Very low $\mathrm{IC}_{50}$-values for TEMPO in the system of phenol nitration have been reported [67] and were confirmed in our system ( $\mathrm{IC}_{50}$-values of less than $2 \mu \mathrm{M}$ ). Nevertheless, 4-nitrosophenol levels where increased, supporting previously postulated mechanism for this reaction [67].

\subsection{Scavengers of Peroxynitrite Inhibiting the Nitrosation of Phenol}

The nitrosation of phenol by peroxynitrite was investigated at $\mathrm{pH} 9$ using the same set of scavengers (Table 1). Again, uric acid derivatives and the thio-purines and -pyrimidines were best in inhibiting phenol nitrosation, suggesting that this process also involves radical species. Furthermore, at alkaline $\mathrm{pH}$, high amounts of biphenols were formed, implicating the involvement of phenoxy radicals [63], for which the same group of scavengers is most effective.

\subsection{Scavengers of Peroxynitrite Inhibiting the Nitration of BSA}

The results on phenol nitration could be reproduced in another test system where the same scavengers attenuated peroxynitrite-mediated BSA nitration (Table 2). Again, uric acid, 1,3-DMUA and 2-TBA were the most efficient compounds in inhibiting the nitration of tyrosine residues in BSA. 
Table 2. Half-maximal inhibition concentrations ( $\mathrm{IC}_{50}$-values) of various compounds for the nitration of bovine serum albumin $(15 \mu \mathrm{M})$ by peroxynitrite $(1 \mathrm{mM})$ at $\mathrm{pH} 7$.

\begin{tabular}{cccc}
\hline Scavenger & $\mathbf{I C}_{\mathbf{5 0}}(\boldsymbol{\mu M})$ & Scavenger & $\mathbf{I C}_{\mathbf{5 0}}(\boldsymbol{\mu M})$ \\
\hline Glutathione & $150 \pm 26$ & Methionine & $200 \pm 38$ \\
Ascorbate & $170 \pm 17$ & Uric acid & $75 \pm 13$ \\
2-Thiobarbituric acid & $45 \pm 12$ & 1,3-Dimethyluric acid & $60 \pm 14$ \\
Ebselen & $180 \pm 12$ & 3,7-Dimethyluric acid & $185 \pm 37$ \\
Xanthine & $>500$ & 3,9-Dimethyluric acid & $>200$ \\
Allopurinol & $>500$ & - & - \\
\hline
\end{tabular}

\subsection{Scavengers of Peroxynitrite Inhibiting the Metal-Catalyzed Nitration of Phenol}

In an additional series of experiments, a system containing phenol and MP-11 was used as a model for the metal-catalyzed tyrosine nitration of proteins. Nitration of $5 \mathrm{mM}$ phenol by $655 \mu \mathrm{M}$ peroxynitrite at $\mathrm{pH} 6$ was increased by a factor of 4 to 5 by $5 \mu \mathrm{M} \mathrm{MP}-11$. The same scavengers as the ones tested above were used in this system and for the first time it turned out that also for the metal-catalyzed nitration, uric acid, 1.3-DMUA, 2.6-DTPu and -DTPy were much more effective in inhibiting phenol nitration than GSH, ascorbate, ebselen, methionine and Se-methionine (Figure S10 in supplementary information). Only 2-TBA showed a surprisingly low efficacy in this system.

\subsection{Scavengers of Peroxynitrite Inhibiting the Oxidation and Inactivation of Alcohol Dehydrogenase}

As a second test-system we used $\mathrm{ONOO}^{-}$-mediated oxidation of alcohol dehydrogenase (ADH). The protecting effect of the various scavengers on ADH-activity directly correlated with the reactivity of the scavengers towards the peroxynitrite-anion. Beckman et al. previously reported sensitive thiol-oxidation and ADH-inactivation at low peroxynitrite concentrations [68]. We confirmed these findings in a subsequent publication [48] and with the data presented here (Figures S11 and S12 in supplementary information). The $\mathrm{IC}_{50}$-value for peroxynitrite was around 1 to $2 \mu \mathrm{M}$, for $\cdot \mathrm{NO}$ alone (from the hydrolysis of diethyl NONOate). In air-saturated solution it was at least 5-fold higher and in deoxygenated solutions it increased by a factor 10 [48]. Table 3 shows the effect of peroxynitrite scavengers in this system and it turned out that uric acid derivatives, tyrosine and tryptophan showed very low protection of $\mathrm{ADH}$ from oxidation by $20 \mu \mathrm{M}$ peroxynitrite, whereas $\mathrm{GSH}$, cysteine, Se-methionine, and to a lesser extent methionine, were highly efficient in preventing ADH inactivation. As a control we verified that the scavengers used could not reactivate already inactivated ADH. 2.6-DTPy and -DTPu also showed a protective activity in this system, but led themselves to the inhibition of the enzyme, when used at higher concentrations, thereby preventing them from completely preserving ADH activity. Ebselen, which is known to react with thiols to form adducts [59] inhibited ADH already at $\mathrm{nM}$ concentrations (Figure S11 in supplementary information). Ascorbate seemed to form intermediates with peroxynitrite (probably ascorbyl radicals), which also inhibited $\mathrm{ADH}$. Therefore, the maximal protection of ADH activity obtained with ascorbate did not exceed $60 \%$. 
Table 3. Half-maximal inhibition concentrations ( $\mathrm{IC}_{50}$-values) of various compounds for the inactivation of alcohol dehydrogenase $(26 \mathrm{nM})$ by peroxynitrite $(20 \mu \mathrm{M})$.

\begin{tabular}{cccc}
\hline Scavenger & $\mathbf{I C}_{\mathbf{5 0}}(\boldsymbol{\mu M})$ & Scavenger & IC $_{\mathbf{5 0}}(\boldsymbol{\mu M})$ \\
\hline Glutathione & $31 \pm 2.5$ & Methionine & $185 \pm 7$ \\
Ascorbate & $* * *$ & Uric acid & $400 / 26 \pm 2 *$ \\
2,6-Dithiopurine & $40 \pm 5 * *$ & 2,6-Dithiopyrimidine & $45 \pm 8 * *$ \\
Ebselen & $* * *$ & 3,7-Dimethyluric acid & $400 / 42 \pm 1.5 *$ \\
Se-methionine & $15 \pm 1$ & Tryptophan & $400 / 35 \pm 3 *$ \\
Cysteine & $18 \pm 3$ & Tyrosine & $420 \pm 30$ \\
\hline
\end{tabular}

* highest concentration of scavenger/percentage of preserved ADH-activity at this concentration; ** scavenger itself reduced ADH-activity by $20 \%$ when used at $50 \mu \mathrm{M}$; *** strong inhibition of ADH by ebselen and probably a product from the peroxynitrite-ascorbate reaction.

\section{Discussion}

Nitric oxide $(\cdot \mathrm{NO})$ and superoxide $\left(\cdot \mathrm{O}_{2}^{-}\right)$are two endogenously formed radical species in biological systems. Although they exert minor reactivity towards organic molecules when present alone, both radicals can combine in an almost diffusion-limited process to form peroxynitrite [69]. For this product, a high reactivity towards biological macromolecules has been observed, e.g., DNA strand breaks [70], fatty acids oxidation [71-74], and numerous modifications of proteins such as thiol oxidation $[47,48,68]$, sulfoxidation of methionine residues [7,75,76] and tyrosine nitration [26,29,43,77]. Therefore, peroxynitrite might account for numerous deleterious effects associated with nitro-oxidative stress. Indeed, by using tyrosine nitration as a footprint of endogenous peroxynitrite formation, an association with Alzheimer's Disease, hypoxia [78], hypoglycemia [79], shock, allograft rejection, stroke and other cardiovascular and neurodegenerative diseases has been postulated (for reviews see [10,11,18,20,24]).

Our interest in mechanistic and analytical details of tyrosine nitration was derived from the high sensitivity and selectivity of PGIS nitration and inhibition [29,80]. Pure enzyme preparations reacted with $\mathrm{IC}_{50}$-values of around $100 \mathrm{nM}$ peroxynitrite [81] and even in whole cells and aortic tissue such low values were observed $[29,42,80,82]$. This was puzzling considering the many antioxidants and potential other peroxynitrite targets in cellular systems. It might however partially be explained by the localization of PGIS in caveolae of the plasma membrane [83], which allow direct access of peroxynitrite to the enzyme. It also should be mentioned that for peroxynitrite an assessment of $\mathrm{IC}_{50}$-values has to take into account its high reactivity which leads to rapid changes of its steady state concentrations in the presence of varying concentrations of competing substrates. This becomes important when comparing inhibitory concentrations of peroxynitrite for pure proteins and protein homogenates which is most conclusively demonstrated by the effect of aortic microsomes on exogenous BSA nitration by peroxynitrite. The sensitive nitration and inactivation of PGIS on one hand, and the increased production of the PGIS substrate $\mathrm{PGH}_{2}$ by enhanced cyclooxygenase activity in the presence of higher peroxide concentrations (e.g., hydrogen peroxide, lipid peroxides, peroxynitrite), provides the basis for an efficient redox-regulatory system of the vascular tone $[55,84,85]$. Based on this increased activity of the COX/PGIS pathway due to an increased peroxide tone, some pathological situations such as dilated cardiomyopathy, or genetically-induced 
hypertension, are associated with increased prostacyclin levels despite increased reactive oxygen species levels and decreased nitric oxide bioavailability $[86,87]$.

Our second aim was to evaluate the use of anti-nitrotyrosine antibodies, since their use has been questioned in terms of specificity and sensitivity. We could observe a good correlation between Western blot staining and 3-nitrotyrosine levels, detected by HPLC analysis after pronase digestion - but there are cases where 3-nitrotyrosine containing epitopes react better with monoclonal than with polyclonal Ab's and vice versa. Since the catalytic sites of metallo-enzymes are usually buried, a proper unfolding of the protein is required to obtain sufficient sensitivity. This may require repeated stripping of the membrane e.g., in the case of PGIS in order to ensure proper denaturation of the enzyme. We were able to show that PGIS can be nitrated by rather low concentrations of peroxynitrite and that part of the purified enzyme already exhibits tyrosine nitration. Pronase digestion for up to 6 days is required to achieve a complete hydrolysis of PGIS, whereas other soluble proteins like BSA required only 2-3 h. Meanwhile, the nitrated tyrosine has been identified at position 430 by LC-FTICR-MS, which is close to the heme-thiolate active site in the normal 3-dimensional configuration of active PGIS [41].

With this background, the search for pharmacologically active inhibitors of the presumed deleterious actions of peroxynitrite becomes possible. However, the reactions involving peroxynitrite may not all be deleterious as we have presented evidence that PGIS undergoes tyrosine nitration and inactivation at very low peroxynitrite concentrations, suggesting a physiological regulatory role of this posttranslational modification $[29,42,80]$. This reaction seems to be auto-catalyzed by the active heme site of the enzyme since substrate analogues which blocked the active site decreased its nitration [29]. By using other $\mathrm{P} 450$ proteins ( $\mathrm{P} 450_{\mathrm{CAM}}$ and $\mathrm{P} 450_{\mathrm{BM}-3}$ ) we were able to prove that this autocatalytic nitration by peroxynitrite occurs with other members of this family of proteins [33,34]. Based on these observations, the nitration of PGIS seems to fulfill a regulatory role. In order to prove this hypothesis, we tested for scavengers of this process but were not successful [39] except for ebselen which turned out to compete with PGIS nitration. This however occurred only in the absence of thiols, making it unsuitable for cellular or even in vivo inhibition experiments [59]. This has stimulated our interest in a rational design of peroxynitrite scavengers but according to the literature and our own results, this topic proved to be difficult due to the different forms under which peroxynitrite can exert its actions.

Considering that peroxynitrite's oxidizing properties correlate with its readiness to undergo $\mathrm{O}-\mathrm{O}$ bond cleavage to give a radical pair of $\mathrm{HO} \cdot$ and $\cdot \mathrm{NO}_{2}$, its reactivity will depend on the neutralization of its anion by a proton $\left(\mathrm{p} K_{\mathrm{a}}=6.8\right)$ [88] or by formation of an oxo species in the presence of suitable transition metal ions, like $\mathrm{Mn}^{2+}$ or $\mathrm{Mn}^{3+}, \mathrm{Cu}^{2+}$ or preferentially $\mathrm{Fe}^{3+}$ [25]. The latter yields ferryl complexes [formally $\mathrm{Fe}(\mathrm{IV})=\mathrm{O}$ ] in heme when reacting with peroxynitrite. The nitration of PGIS has been explained the same way. In the absence of a metal ion, a proton is required and hence $\mathrm{pH}$ values below 6 are required to generate sufficient quantities of peroxynitrous acid. This acid form can be thermally excited to dissociate into a radical pair [HO $\cdot O \mathrm{ONO}]_{\text {cage }}[24]$ by which an oxidative attack on organic compounds can be initiated. Efficient scavengers of this type of reactions preferentially react with the radical cage form of peroxynitrite or derived free radicals and usually show a clear $\mathrm{pH}$-dependence in their reactivity (e.g., uric acid, Figure S10 in supplementary information). Alternatively, if suitable substrates are lacking, isomerization to nitrate can occur or it will react with a second peroxynitrite molecule leading to dioxygen and dinitrogen trioxide $\left(\mathrm{N}_{2} \mathrm{O}_{3}\right)$ which is easily 
hydrolyzed to nitrite [89]. Since this reaction is unavoidable at the concentrations usually used, the nitrosating properties of $\mathrm{N}_{2} \mathrm{O}_{3}$ also have to be considered [48,63].

In the peroxynitrite literature, all reactions involving homolytic OO-bond cleavage have been summarized as "1e-oxidations" in contrast to a few reactions which transfer one oxygen atom from peroxynitrite and therefore have been termed "2e-oxidations". The formation of ebselen-oxide from ebselen [58,59] or the sulfoxide from methionine [49,50] are examples of this type of reaction which can originate from the peroxynitrite anion as evidenced by the $\mathrm{pH}$-independence of such oxidations (e.g., ebselen, Figure S11 in supplemental information). To further complicate the reaction pattern of peroxynitrite, its anion can behave as a nucleophile and form adducts, e.g., with carbonyls. The peroxo compound arising from carbon dioxide is a well-studied example of this reaction $[35,36]$.

Considering the plethora of oxidations by peroxynitrite, it is obvious that no specific inhibitor or scavenger will be identified, but only mechanism-based subtypes can be found. Lots of results have been published previously concerning the peroxynitrite scavenging properties of natural and synthetic compounds [56,90,91]. In addition, lots of different test systems have been used to compare these compounds [92], especially the $\alpha_{1}$-antiproteinase-elastase system which was used to test the effects of peroxynitrite scavengers on methionine oxidation and $\alpha_{1}$-antiproteinase inactivation $[56,90]$. In the present study, phenol was used as a substrate since previous reports suggested that the "1e-oxidation" pathway leads to a phenoxy-radical to which an $\cdot \mathrm{NO}_{2}$ radical can add to form 2- and 4-nitrophenol [63]. By measuring this parameter, which also closely mimics the nitration of tyrosine residues in proteins, we attempted to define a basis for peroxynitrite scavengers.

One of the aims of the present study was to reinvestigate a series of organic compounds as potential inhibitors of peroxynitrite actions with a particular emphasis on biologically occurring substances as potential lead structures. Among them there would be compounds such as ascorbate or tocopherols, but also carbonyl derivatives since carbon dioxide is known to form an addition product with the peroxynitrite anion [35,93]. Our main interest, however, was focused on uric acid which had been described as an exceptionally good scavenger of peroxynitrite [56,57,94]. As a test system we measured the hydroxylation and nitration of phenol [63], which not only allowed to monitor the formation of the radical pair but also served as a model for tyrosine nitration in proteins. The analytics and the mechanisms involved were recently published [63] and have been extended to heme catalysis [32,39]. Another aim of this study was to distinguish between scavengers which mainly react with the protonated form of peroxynitrite and those which show high reactivity for the peroxynitrite-anion. For this reason, we used an enzymatic system based on ADH-activity as a second test system. For ADH, Beckman and coworkers reported a $k$-value of $4 \times 10^{5} \mathrm{M}^{-1} \mathrm{~s}^{-1}$ for the reaction with the peroxynitrite-anion [68]. Therefore, this enzyme seemed to be a perfect test system to monitor the scavenging ability and the protective effects of the antioxidant compounds to be tested. Furthermore decomposition kinetics of peroxynitrite at alkaline $\mathrm{pH}$ are supposed to indicate if a compound is able to react directly with peroxynitrite-anion or if it is involved in the reaction of the protonated form or one of the decomposition intermediates. 


\section{Materials and Methods}

\subsection{Materials}

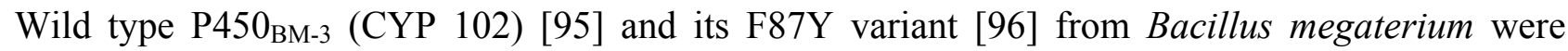
kindly donated by J.A. Peterson (TX, USA) and expressed and purified as described. P450 $\mathrm{CAM}$ (E.C. 1.14.14.1) from Pseudomonas putida was a kind gift of C. Jung (Max-Delbrück-Centrum, Berlin,

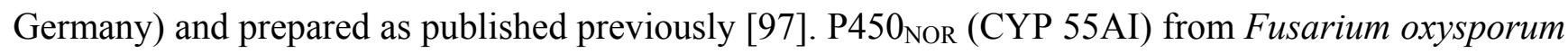
was a kind gift of H. Shoun and N. Takaya (University of Tokyo, Tokyo, Japan) and purified as described previously [98]. Human PGIS (E.C. 5.3.99.4) was overexpressed in Spodoptera frugiperda 21 (Sf21) cells and partially purified as recently described [99]. The microsomal concentration of PGIS was determined by the tranylcypromine binding-spectrum to be $3.3 \mu \mathrm{M}(200 \mu \mathrm{g} / \mathrm{mL})$ at a total protein concentration of $1 \mathrm{mg} / \mathrm{mL}$ [99]. PGIS activity was determined using ${ }^{14} \mathrm{C}$-prostaglandin endoperoxide $\mathrm{H}_{2}\left(\mathrm{PGH}_{2}\right)$ as previously described [99]. Cu,Zn-SOD (EC 1.15.1.1) from bovine erythrocytes, CPO (EC 1.11.1.10) from Caldariomyces fumago, xanthine oxidase (E.C. 1.1.3.22) grade III from buttermilk and BSA were purchased from Sigma (Steinheim, Germany). Pronase from Streptomyces griseus (lyophylized powder) was obtained from Roche (Mannheim, Germany) and thermolysine from Bacillus thermoproteolyticus rokko (type X) was from Sigma (St. Louis, MO, USA). Sin-1 hydrochloride (3-morpholinosydnonimine $\mathrm{HCl}$ ) was from Calbiochem-Novabiochem Corporation (La Jolla, CA, USA). Spermine NONOate ( $N$-[4-[1-(3-aminopropyl)-2-hydroxy-2nitrosohydrazino]butyl]-1,3-propanediamine) was purchased from Cayman Chemical Company (Ann Arbor, MI, USA). The protease inhibitor cocktail (general use) was prepared according to the product information from Sigma-Aldrich (Steinheim, Germany). Peroxynitrite was a kind gift of M. Mehl (Department of Inorganic Chemistry, ETH Zürich, Switzerland) and synthesized as described by Kissner and Koppenol [69] from $\cdot \mathrm{NO}$ and potassium superoxide and depleted of residual $\mathrm{H}_{2} \mathrm{O}_{2}$ with $\mathrm{MnO}_{2}$. The dimethyluric acid derivatives and dithiopurine and -pyrimidine were purchased from Sigma-Aldrich. Ebselen was a kind gift from A. Wendel (University of Konstanz, Konstanz, Germany). TEMPONE and TEMPO were purchased from Alexis (Loerrach, Germany). All other chemicals were of analytical grade.

\subsection{Nitration of Purified, Recombinant PGIS Protein by in Situ Generated Peroxynitrite from Sin-1}

Purified, recombinant PGIS protein was a kind gift from Dr. C.S. Raman (Department of Pharmaceutical Sciences, University of Maryland, Baltimore, MD, USA) and Dr. P. Nioche (Université Paris Descartes, INSERM UMR-S 747, Paris, France) and prepared according to previous reports with some modifications [100]. Conditions of incubation were as described in the legend to Figure 4 and Western blot analysis as well as dot blot analysis were performed as described previously $[101,102]$ using a monoclonal anti-3-nitrotyrosine antibody at a dilution of 1:1000 (Upstate Biotechnology/Millipore, Lake Placid, NY, USA) and a polyclonal anti-PGIS antibody at a dilution of 1:250 (Cayman Europe, Tallinn, Estonia). 


\subsection{Nitration of P450 ${ }_{B M-3}$ Proteins and PGIS by either Authentic Peroxynitrite or in Situ Generated Peroxynitrite from Sin-1 or Xanthine Oxidase/Spermine NONOate}

Human PGIS (3.3 $\mu \mathrm{M}, 200 \mu \mathrm{g} / \mathrm{mg}$ total protein) overexpressed in Spodoptera frugiperda 21 (Sf21) cells was used as a partially purified microsomal suspension $(1 \mathrm{mg} / \mathrm{mL}$ total protein) in $0.1 \mathrm{M}$ potassium phosphate buffer $\mathrm{pH}$ 7.4. Bovine PGIS was used as a suspension of aortic microsomes ( $1 \mathrm{mg} / \mathrm{mL}$ total protein) in $0.1 \mathrm{M}$ potassium phosphate buffer $\mathrm{pH} 7.5$ as previously described [41]. Purified $\mathrm{P} 450_{\mathrm{BM}-3}$ proteins were used at a concentration of $2.5 \mu \mathrm{M}$. A small aliquot of peroxynitrite (100 $\mathrm{mM}$ in $0.1 \mathrm{M} \mathrm{NaOH}$ ) was added by rapid mixing of the reaction solutions and was allowed to completely decompose. Sin-1 (100 $\mu \mathrm{M}$ from a $0.1 \mathrm{M}$ acidic stock solution) or xanthine oxidase $(2.8 \mathrm{mU} / \mathrm{mL})$ and/or spermine NONOate $(100 \mu \mathrm{M}$ from a $0.1 \mathrm{M}$ alkaline stock solution) were added to the protein solutions and incubated for $90 \mathrm{~min}$ at $37^{\circ} \mathrm{C}$ to allow complete decomposition.

\subsection{Inhibition of Nitration by Peroxynitrite Scavengers and Substrate Analogue Inhibitors}

Palmitate, a natural substrate of $\mathrm{P} 450_{\mathrm{BM}-3}$, was used from a stock solution in DMSO. Palmitate $(25-250 \mu \mathrm{M})$ was preincubated with wild type $\mathrm{P} 450_{\mathrm{BM}-3}$ or its $\mathrm{F} 87 \mathrm{Y}$ variant (4 and $2 \mu \mathrm{M}$, respectively) and all samples were adjusted with pure DMSO, so that all of them contained 1\% $v / v$ of DMSO. These amounts of DMSO and palmitate did not interfere with peroxynitrite-, Sin-1- or xanthine oxidase/spermine NONOate-mediated nitration of P450 $0_{\mathrm{BM}-3}$. Peroxynitrite scavengers $(50$ and $100 \mu \mathrm{M})$ such as ascorbate, glutathione and phenol were added together with $\mathrm{P} 450_{\mathrm{BM}-3} \mathrm{~F} 87 \mathrm{Y}$ variant $(0.5 \mu \mathrm{M})$ before mixing with Sin-1 $(100 \mu \mathrm{M})$. BSA $(5 \mu \mathrm{M})$ was treated with peroxynitrite $(50-250 \mu \mathrm{M})$ in the presence and absence of bovine coronary microsomes $(1 \mathrm{mg} / \mathrm{mL}$ total protein).

\subsection{Western Blot Analysis of Nitrated Proteins}

The nitration of $\mathrm{P} 450_{\mathrm{BM}-3}$ proteins and PGIS was detected by Western blot analysis, using a mouse monoclonal anti-3-nitrotyrosine antibody from Upstate Biotechnology (Hamburg, Germany) at a dilution of 1:1000 together with an HRP-conjugated secondary antibody (GAM-POX, 1:7500) which was obtained from Pierce (Rockford, IL, USA). Additionally a rabbit polyclonal anti-3-nitrotyrosine antibody from Upstate Biotechnology was used at a dilution of 1:1000 together with an HRP-conjugated secondary antibody (GAR-POX, 1:3000) from Pierce (Rockford, IL, USA). PGIS was detected with a rabbit polyclonal antibody which was produced according to the method of Siegle et al. and was used at a dilution of $1 \mu \mathrm{g} / \mathrm{mL}$ PBS [103]. Proteins were separated by SDS-PAGE on Novex 8\% Tris-glycine gels (12 wells) from Invitrogen Corporation (Carlsbad, NM, USA). 2.5-10 $\mu \mathrm{L}$ of each sample in Laemmli buffer were loaded on the gels, the running buffer consisted of $25 \mathrm{mM}$ Tris, $192 \mathrm{mM}$ glycine and $5 \mathrm{mM}$ SDS at a current of $35 \mathrm{~mA}$ for $1 \mathrm{~h}$. Proteins were transferred by the semi-dry blotting procedure to a nitrocellulose membrane as described previously [41]. Finally the blot was developed with Super Signal ECL kit from Pierce. To compare the monoclonal and polyclonal hybridizations, the membranes were stripped after monoclonal hybridization and then reprobed with the polyclonal antibody. PGIS samples were always hybridized first with the PGIS antibody, then stripped one or even two times before staining with the anti-3-nitrotyrosine antibody. Epitope recognition of nitrated PGIS depends on strong denaturing conditions (SDS in the stripping 
buffer) to achieve a complete unfolding of the protein, which allows tight binding of the anti-3-nitrotyrosine antibody.

\subsection{Proteolytic Digestion of Nitrated Proteins by Pronase and Direct Detection of 3-Nitrotyrosine}

Pronase digestion was performed as previously described for $\mathrm{P} 450_{\mathrm{BM}-3}$ and $\mathrm{P} 450_{\mathrm{CAM}}[33,34]$. Briefly, nitrated PGIS $(3.3 \mu \mathrm{M})$ in $0.1 \mathrm{M}$ potassium phosphate buffer $\mathrm{pH} 7.4$ was prepared for the total protein hydrolysis by pronase: $1 \mathrm{mM} \mathrm{CaCl}_{2}$ for the stabilization of the proteases was added together with $5 \% v / v$ acetonitrile for protein denaturation and better solubility of the liberated amino acids. These samples were incubated with $2 \mathrm{mg} / \mathrm{mL}$ pronase for $24 \mathrm{~h}$ at $37^{\circ} \mathrm{C}$, followed by another addition of $2 \mathrm{mg} / \mathrm{mL}$ pronase. This last step was repeated once after $48 \mathrm{~h}$. The digestion of PGIS was complete after 3 days whereas for other P450 proteins it was already complete within 2-3 h after addition of pronase. The digested samples were depleted from residual proteins by size exclusion centrifugation with a $10 \mathrm{kDa}$ cut-off (Microcon, Millipore Corporation, Bedford, OH, USA) and the eluates were kept at $4{ }^{\circ} \mathrm{C}$ and measured within the next $48 \mathrm{~h}$. 3 and $30 \mathrm{kDa}$ devices were also tested. Several experiments have been conducted to ensure that hydrolysis was complete under these conditions within the indicated time scale. An aliquot $(100 \mu \mathrm{L})$ of each sample was analyzed by HPLC as described previously [26]. Examples of HPLC chromatograms are shown for P450 ${ }_{\text {CAM }}$ and BSA in the online supplement (Figures S13 and S14).

\subsection{Stability of the Nitrated Peptide from PGIS and Specificity of Cleavage by Thermolysine}

Two peptides with the sequence of bovine PGIS and inserted 3-nitrotyrosine have been purchased from Jerini (Berlin, Germany). The first one contained 4 amino acids $\left.\mathrm{NH}_{2}-\mathrm{LKNY}_{(\mathrm{NO}}\right)-\mathrm{OH}$ $(M W=581.3 \mathrm{~g} / \mathrm{mol})$ and the second one contained 16 amino acids $\mathrm{NH}_{2}$-KDGKRLKNY $\left(\mathrm{NO}_{2}\right)$ NMPWGAG-OH $(M W=1879.3 \mathrm{~g} / \mathrm{mol})$. To test the stability of the short peptide and the selectivity of cleavage in the long peptide both were subjected to thermolysine digestion. $10 \mu \mathrm{M}$ of peptide in $50 \mathrm{mM}$ Tris $\mathrm{pH} 8.0,4 \mathrm{mM} \mathrm{CaCl}_{2}$ and $10 \% v / v$ acetonitrile were incubated for $24 \mathrm{~h}$ at $50{ }^{\circ} \mathrm{C}$ together with thermolysine $(25 \mu \mathrm{g} / \mathrm{mL})$. After this time period another $125 \mu \mathrm{g} / \mathrm{mL}$ thermolysine were added and incubation was continued for $60 \mathrm{~h}$ at $37{ }^{\circ} \mathrm{C}$. The mass spectrometry analysis was performed by Dr. Andrea Kiehne from the application department of Bruker Daltonics GmbH (Bremen, Germany). The samples were diluted in $0.1 \%$ formic acid in water yielding a final peptide concentration of $500 \mathrm{fmol} / \mu \mathrm{L} .1 \mu \mathrm{L}$ of these samples was injected into a NanoLC-MS system esquire 3000 plus from Bruker Daltonics (Bremen, Germany). The conditions were as follows: $\mathrm{A} \mathrm{C}_{18}$ PepMap (15 $\mathrm{cm} \times 75 \mu \mathrm{m}$ inner diameter) column and a mobile phase gradient (A: $0.1 \%$ formic acid in water, B: $0.1 \%$ formic acid in $90 \%$ acetonitrile, $0-15 \mathrm{~min} 2 \% \mathrm{~B}$ isocratic, $15-25 \mathrm{~min} 2 \%-90 \%$ $\mathrm{B}, 25-35 \mathrm{~min} 90 \% \mathrm{~B}$ isocratic, 35-40 $\min 90 \%-2 \% \mathrm{~B}$ and $40-70 \mathrm{~min} 2 \% \mathrm{~B}$ isocratic). The flow rate was $200 \mathrm{~nL} / \mathrm{min}$ and optical detection at $214 \mathrm{~nm}$ was used. The parameters for mass spectrometry analysis were determined by a direct injection experiment. Peptides were identified by full scan MS as well as MS/MS with ion capture at $291.6 \mathrm{~m} / \mathrm{z}$. 


\subsection{Alcohol Dehydrogenase Activity}

The activity of $26 \mathrm{nM} \mathrm{ADH}$ with $300 \mu \mathrm{M} \mathrm{NAD}^{+}$for the conversion of $172 \mathrm{mM}$ ethanol to acetaldehyde in $0.1 \mathrm{M}$ potassium phosphate buffer $\mathrm{pH} 7.6$ was followed by spectroscopy at $37{ }^{\circ} \mathrm{C}$ on an Aminco DW-2 dual beam spectrophotometer equipped with a magnetic stirrer and connected to a computer. We measured the kinetics of NADH formation at $340 \mathrm{~nm}$ and the basic specific activity was calculated from the slope of the linear part of the curve (first $25 \mathrm{~s}$ ) to be $245 \pm 20 \mathrm{U} / \mathrm{mg}$. In a next step the amount of peroxynitrite necessary for a complete inhibition of the enzyme was estimated. Therefore the ethanol and $\mathrm{NAD}^{+}$were added after complete reaction of the ADH with peroxynitrite ( $5 \mathrm{~min}$ ) and the activity was measured. We found that $20 \mu \mathrm{M}$ peroxynitrite quantitatively inhibited $\mathrm{ADH}$. In the following step we estimated the $\mathrm{IC}_{50}$-values of several peroxynitrite-scavengers in this system by addition of different concentrations of scavenger to the $\mathrm{ADH}$, before the addition of peroxynitrite. The $\mathrm{IC}_{50}$-value of the scavenger corresponds to the concentration at which $50 \%$ of the $\mathrm{ADH}$ activity is preserved.

\subsection{Nitration of Phenol}

Five millimolars of phenol and $800 \mu \mathrm{M}$ peroxynitrite were incubated in $0.5 \mathrm{M}$ potassium phosphate buffer $\mathrm{pH} 7$ at $25{ }^{\circ} \mathrm{C}$. The formation of 2- and 4-nitrophenol was followed by spectrophotometry at $405 \mathrm{~nm}$ (after addition of $2 \% v / v$ saturated $\mathrm{NaOH}$ ) or by separation of $2-\left(t_{\mathrm{R}}=28 \mathrm{~min}\right.$ ) and 4-nitrophenol $\left(t_{\mathrm{R}}=16 \mathrm{~min}\right.$ ) by HPLC (system II, $1 \mathrm{~mL} / \mathrm{min}, 30 \%$ acetonitrile and $75 \% 0.1 \mathrm{M}$ citrate buffer $\mathrm{pH} 2$, Bischoff $\mathrm{C}_{18}$-Nucleosil-100-5 $250 \times 4.6$, detection at $280 \mathrm{~nm}$ ). For the $\mathrm{IC}_{50}$-values, the scavengers were added before addition of peroxynitrite by vortex-mixing and $\mathrm{IC}_{50}$-values correspond to the concentrations of scavengers, at which the $405 \mathrm{~nm}$ absorbance or nitrophenol peak-area were $50 \%$ of that measured in the absence of scavengers. $5 \mathrm{mM}$ phenol was incubated either with $655 \mu \mathrm{M}$ peroxynitrite in $0.2 \mathrm{M}$ potassium phosphate buffer $\mathrm{pH} 6(1 \mathrm{~min})$ or with $400 \mu \mathrm{M}$ peroxynitrite at $\mathrm{pH} 9$ $(10 \mathrm{~min})$ and $37^{\circ} \mathrm{C}$. At $\mathrm{pH} 6$ the formation of $2-\left(t_{\mathrm{R}}=15.6 \mathrm{~min}\right)$ and 4-nitrophenol $\left(t_{\mathrm{R}}=12.8 \mathrm{~min}\right)$ was monitored by HPLC (system I, $1 \mathrm{~mL} / \mathrm{min}, 10 \%$ acetonitrile and $90 \% 0.05 \mathrm{M}$ citrate buffer $\mathrm{pH} 2$, Macherey-Nagel $\mathrm{C}_{4}$-Nucleosil-300-5 $250 \times 4.6$, detection $280 \mathrm{~nm}$ ). At $\mathrm{pH} 9$ the formation of 4-nitrosophenol $\left(t_{\mathrm{R}}=11 \mathrm{~min}\right)$ was either followed vy spectrophotometry at $395 \mathrm{~nm}$ or by HPLC (system I, $1 \mathrm{~mL} / \mathrm{min}, 10 \%$ acetonitrile and 90\% $0.05 \mathrm{M}$ citrate buffer $\mathrm{pH} \mathrm{2,} \mathrm{Macherey-Nagel}$ $\mathrm{C}_{18}$-Nucleosil-100-5 $250 \times 4.6$, detection $300 \mathrm{~nm}$ ). The $\mathrm{IC}_{50}$-values were estimated as described above.

\subsection{Metal-Catalyzed Nitration of Phenol}

The method used was similar to the one used in the phenol system at $\mathrm{pH} 6$, but with $5 \mu \mathrm{M}$ microperoxidase (MP-11) (a porphyrin with 11 amino acids originating from the degradation of cytochrome c). MP-11 like other heme containing enzymes and iron-porphyrins leads to a strong increase in nitration of phenol. No $\mathrm{IC}_{50}$-values were estimated, but the effect of $100 \mu \mathrm{M}$ scavenger on nitration was monitored using HPLC. 


\subsection{Kinetics of Peroxynitrite-Decomposition}

Decay of peroxynitrite was followed by UV/Vis spectroscopy by the difference in absorbance at $302 \mathrm{~nm}$ and the reference wavelength at $400 \mathrm{~nm}$. The samples were measured in a special cuvette which was equipped with a magnetic stirrer. Because of inadequate mixing during the first 2-3 s the decomposition curves were only compared qualitatively and no kinetic constants could be obtained from these measurements. $400-800 \mu \mathrm{M}$ peroxynitrite was injected into a stirred $\mathrm{pH} 7,8$ or 9 buffer solution which contained the scavenger at different concentrations. The velocity of decay was then compared with the one in controls.

\section{Conclusions}

The results of the present study show that metal catalysis adds efficacy and selectivity to peroxynitrite-mediated nitration reactions. Partially purified PGIS showed complete nitration at a peroxynitrite concentration of $10 \mu \mathrm{M}$ (3-fold molar excess). This was surprising since the nitrotyrosine formation took place under reducing (antioxidant) conditions mimicked by the microsomes' sulfhydryl environment thereby underlining the high velocity and specificity of this nitration reaction. We also identified carbon dioxide mediated catalysis of PGIS nitration as an alternative or synergistic pathway of PGIS nitration besides the metal-catalyzed nitration process under physiological conditions. Although the carbon dioxide mediated nitration of PGIS was also inhibited by an active site inhibitor of PGIS, U-51605, it remains to be established whether carbon dioxide-catalyzed nitration targets the same tyrosine residue as the metal-catalyzed process since previous reports did not observe an effect of carbon dioxide on inactivation of PGIS by peroxynitrite [29]. In contrast, we can exclude a major contribution of freely diffusing $\cdot \mathrm{NO}_{2}$-radicals to the nitration of PGIS since peroxidase/nitrite/hydrogen peroxide systems were rather inefficient in conferring this nitration process. A valid model for PGIS with respect to nitration is the bacterial monooxygenase $\mathrm{P} 450_{\mathrm{BM}-3}$. Activated thio-compounds such as 2,6-dithiopurine and -pyrimidine proved to be highly efficient scavengers of the various forms of peroxynitrite: the anion $\left(\mathrm{ONOO}^{-}\right)$, the protonated form $(\mathrm{ONOOH})$ as well as derived free radicals $\left(\mathrm{HO} \cdot\right.$ and $\left.\cdot \mathrm{NO}_{2}\right)$. All other compounds had more or less pronounced preferences for one of the peroxynitrite species: thiol- and seleno-compounds as well as thioethers reacted most efficiently with the anion whereas they only partially inhibited free radical-mediated reactions such as phenol nitration and hydroxylation. Typical one-electron reductants such as ascorbate and uric acid efficiently suppressed nitration and hydroxylation of phenol. However, it was surprising that structurally-related purines such as xanthine and caffeine did not mimic the effects of uric acid.

\section{Acknowledgements}

We are indebted to K. Burger for her excellent technical assistance. We also thank C.S. Raman (Department of Pharmaceutical Sciences, University of Maryland, Baltimore, USA) and P. Nioche (Université Paris Descartes, INSERM UMR-S 747, Paris, France) for kindly providing the purified, recombinant PGIS protein. This work was supported by a grant from the Deutsche Forschungsgemeinschaft, Schwerpunktprogramm "Radikale in der enzymatischen Katalyse" (U136/25-1) to V.U. and A.D., T.M. and A.D. were supported by the "Stiftung Mainzer Herz". This 
work was supported by NIH grants PO1 HL 068758 and R37 HL104017 as well as by NHLBI, National Institutes of Health, Department of Health and Human Services, under Contract No. HHSN268201000031C and its contents are solely the responsibility of the authors and do not necessarily represent the official views of the awarding agencies.

\section{Conflict of Interest}

The authors declare no conflict of interest.

\section{References and Notes}

1. Palmer, R.M.; Ferrige, A.G.; Moncada, S. Nitric oxide release accounts for the biological activity of endothelium-derived relaxing factor. Nature 1987, 327, 524-526.

2. Ignarro, L.J.; Buga, G.M.; Wood, K.S.; Byrns, R.E.; Chaudhuri, G. Endothelium-derived relaxing factor produced and released from artery and vein is nitric oxide. Proc. Natl. Acad. Sci. USA 1987, 84, 9265-9269.

3. Daiber, A. Redox signaling (cross-talk) from and to mitochondria involves mitochondrial pores and reactive oxygen species. Biochim. Biophys. Acta 2010, 1797, 897-906.

4. Munzel, T.; Daiber, A.; Ullrich, V.; Mulsch, A. Vascular consequences of endothelial nitric oxide synthase uncoupling for the activity and expression of the soluble guanylyl cyclase and the cgmp-dependent protein kinase. Arterioscler. Thromb. Vasc. Biol. 2005, 25, 1551-1557.

5. Crow, J.P.; Beckman, J.S. Reaction between nitric oxide, superoxide, and peroxynitrite: Footprints of peroxynitrite in vivo. Adv. Pharmacol. 1995, 35, 17-43.

6. Ferdinandy, P. Peroxynitrite: Just an oxidative/nitrosative stressor or a physiological regulator as well? Br. J. Pharmacol. 2006, 148, 1-3.

7. Tien, M.; Berlett, B.S.; Levine, R.L.; Chock, P.B.; Stadtman, E.R. Peroxynitrite-mediated modification of proteins at physiological carbon dioxide concentration: $\mathrm{pH}$ dependence of carbonyl formation, tyrosine nitration, and methionine oxidation. Proc. Natl. Acad. Sci. USA 1999, 96, 7809-7814.

8. Viner, R.I.; Williams, T.D.; Schoneich, C. Peroxynitrite modification of protein thiols: Oxidation, nitrosylation, and $s$-glutathiolation of functionally important cysteine residue(s) in the sarcoplasmic reticulum ca-atpase. Biochemistry 1999, 38, 12408-12415.

9. Daiber, A.; Bachschmid, M. Enzyme inhibition by peroxynitrite-mediated tyrosine nitration and thiol oxidation. Curr. Enzyme Inhib. 2007, 3, 103-117.

10. Turko, I.V.; Murad, F. Protein nitration in cardiovascular diseases. Pharmacol. Rev. 2002, 54, 619-634.

11. Smith, M.A.; Richey Harris, P.L.; Sayre, L.M.; Beckman, J.S.; Perry, G. Widespread peroxynitrite-mediated damage in alzheimer's disease. J. Neurosci. 1997, 17, 2653-2657.

12. Pacher, P.; Beckman, J.S.; Liaudet, L. Nitric oxide and peroxynitrite in health and disease. Physiol. Rev. 2007, 87, 315-424.

13. Ferdinandy, P.; Schulz, R. Nitric oxide, superoxide, and peroxynitrite in myocardial ischaemia-reperfusion injury and preconditioning. Br. J. Pharmacol. 2003, 138, 532-543. 
14. Ullrich, V.; Kissner, R. Redox signaling: Bioinorganic chemistry at its best. J. Inorg. Biochem. 2006, 100, 2079-2086.

15. Ischiropoulos, H. Biological selectivity and functional aspects of protein tyrosine nitration. Biochem. Biophys. Res. Commun. 2003, 305, 776-783.

16. Greenacre, S.A.; Ischiropoulos, H. Tyrosine nitration: Localisation, quantification, consequences for protein function and signal transduction. Free Radic. Res. 2001, 34, 541-581.

17. Brennan, M.L.; Wu, W.; Fu, X.; Shen, Z.; Song, W.; Frost, H.; Vadseth, C.; Narine, L.; Lenkiewicz, E.; Borchers, M.T.; et al. A tale of two controversies: Defining both the role of peroxidases in nitrotyrosine formation in vivo using eosinophil peroxidase and myeloperoxidase-deficient mice, and the nature of peroxidase-generated reactive nitrogen species. J. Biol. Chem. 2002, 277, 17415-17427.

18. Ischiropoulos, H.; Beckman, J.S. Oxidative stress and nitration in neurodegeneration: Cause, effect, or association? J. Clin. Invest. 2003, 111, 163-169.

19. Kooy, N.W.; Royall, J.A.; Ye, Y.Z.; Kelly, D.R.; Beckman, J.S. Evidence for in vivo peroxynitrite production in human acute lung injury. Am. J. Respir. Crit. Care Med. 1995, 151, 1250-1254.

20. Ischiropoulos, H. Biological tyrosine nitration: A pathophysiological function of nitric oxide and reactive oxygen species. Arch. Biochem. Biophys. 1998, 356, 1-11.

21. Beckman, J.S. Protein tyrosine nitration and peroxynitrite. FASEB J. 2002, 16, 1144.

22. Pinzar, E.; Wang, T.; Garrido, M.R.; Xu, W.; Levy, P.; Bottari, S.P. Angiotensin ii induces tyrosine nitration and activation of erk1/2 in vascular smooth muscle cells. FEBS Lett. 2005, 579, 5100-5104.

23. Csibi, A.; Communi, D.; Muller, N.; Bottari, S.P. Angiotensin ii inhibits insulin-stimulated glut4 translocation and akt activation through tyrosine nitration-dependent mechanisms. PLoS One 2010, 5, e10070.

24. Beckman, J.S.; Koppenol, W.H. Nitric oxide, superoxide, and peroxynitrite: The good, the bad, and ugly. Am. J. Physiol. 1996, 271, C1424-C1437.

25. Daiber, A.; Ullrich, V. Peroxynitrite reactions with heme and heme-thiolate (p450) proteins. Methods Enzymol. 2002, 359, 379-389.

26. Daiber, A.; Bachschmid, M.; Beckman, J.S.; Munzel, T.; Ullrich, V. The impact of metal catalysis on protein tyrosine nitration by peroxynitrite. Biochem. Biophys. Res. Commun. 2004, 317, 873-881.

27. Van der Vliet, A.; Eiserich, J.P.; O’Neill, C.A.; Halliwell, B.; Cross, C.E. Tyrosine modification by reactive nitrogen species: A closer look. Arch. Biochem. Biophys. 1995, 319, 341-349.

28. Floris, R.; Piersma, S.R.; Yang, G.; Jones, P.; Wever, R. Interaction of myeloperoxidase with peroxynitrite. A comparison with lactoperoxidase, horseradish peroxidase and catalase. Eur. J. Biochem. 1993, 215, 767-775.

29. Zou, M.; Martin, C.; Ullrich, V. Tyrosine nitration as a mechanism of selective inactivation of prostacyclin synthase by peroxynitrite. Biol. Chem. 1997, 378, 707-713.

30. Zou, M.; Yesilkaya, A.; Ullrich, V. Peroxynitrite inactivates prostacyclin synthase by heme-thiolate-catalyzed tyrosine nitration. Drug Metab. Rev. 1999, 31, 343-349. 
31. Gwozdz, P.; Drelicharz, L.; Kozlovski, V.I.; Chlopicki, S. Prostacyclin, but not nitric oxide, is the major mediator of acetylcholine-induced vasodilatation in the isolated mouse heart. Pharmacol. Rep. 2007, 59, 545-552.

32. Mehl, M.; Daiber, A.; Herold, S.; Shoun, H.; Ullrich, V. Peroxynitrite reaction with heme proteins. Nitric Oxide 1999, 3, 142-152.

33. Daiber, A.; Herold, S.; Schoneich, C.; Namgaladze, D.; Peterson, J.A.; Ullrich, V. Nitration and inactivation of cytochrome p450bm-3 by peroxynitrite. Stopped-flow measurements prove ferryl intermediates. Eur. J. Biochem. 2000, 267, 6729-6739.

34. Daiber, A.; Schoneich, C.; Schmidt, P.; Jung, C.; Ullrich, V. Autocatalytic nitration of p450cam by peroxynitrite. J. Inorg. Biochem. 2000, 81, 213-220.

35. Meli, R.; Nauser, T.; Latal, P.; Koppenol, W.H. Reaction of peroxynitrite with carbon dioxide: Intermediates and determination of the yield of $\operatorname{co}^{*}$ - and no2*. J. Biol. Inorg. Chem. 2002, 7, 31-36.

36. Goldstein, S.; Czapski, G.; Lind, J.; Merenyi, G. Carbonate radical ion is the only observable intermediate in the reaction of peroxynitrite with co(2). Chem. Res. Toxicol. 2001, 14, 1273-1276.

37. Bonini, M.G.; Radi, R.; Ferrer-Sueta, G.; Ferreira, A.M.; Augusto, O. Direct epr detection of the carbonate radical anion produced from peroxynitrite and carbon dioxide. J. Biol. Chem. 1999, 274, 10802-10806.

38. Souza, J.M.; Daikhin, E.; Yudkoff, M.; Raman, C.S.; Ischiropoulos, H. Factors determining the selectivity of protein tyrosine nitration. Arch. Biochem. Biophys. 1999, 371, 169-178.

39. Zou, M.H.; Daiber, A.; Peterson, J.A.; Shoun, H.; Ullrich, V. Rapid reactions of peroxynitrite with heme-thiolate proteins as the basis for protection of prostacyclin synthase from inactivation by nitration. Arch. Biochem. Biophys. 2000, 376, 149-155.

40. Boccini, F.; Herold, S. Mechanistic studies of the oxidation of oxyhemoglobin by peroxynitrite. Biochemistry 2004, 43, 16393-16404.

41. Schmidt, P.; Youhnovski, N.; Daiber, A.; Balan, A.; Arsic, M.; Bachschmid, M.; Przybylski, M.; Ullrich, V. Specific nitration at tyrosine 430 revealed by high resolution mass spectrometry as basis for redox regulation of bovine prostacyclin synthase. J. Biol. Chem. 2003, 278, 12813-12819.

42. Zou, M.; Jendral, M.; Ullrich, V. Prostaglandin endoperoxide-dependent vasospasm in bovine coronary arteries after nitration of prostacyclin synthase. Br. J. Pharmacol. 1999, 126, 1283-1292.

43. MacMillan-Crow, L.A.; Crow, J.P.; Kerby, J.D.; Beckman, J.S.; Thompson, J.A. Nitration and inactivation of manganese superoxide dismutase in chronic rejection of human renal allografts. Proc. Natl. Acad. Sci. USA 1996, 93, 11853-11858.

44. MacMillan-Crow, L.A.; Crow, J.P.; Thompson, J.A. Peroxynitrite-mediated inactivation of manganese superoxide dismutase involves nitration and oxidation of critical tyrosine residues. Biochemistry 1998, 37, 1613-1622.

45. Cassina, A.M.; Hodara, R.; Souza, J.M.; Thomson, L.; Castro, L.; Ischiropoulos, H.; Freeman, B.A.; Radi, R. Cytochrome c nitration by peroxynitrite. J. Biol. Chem. 2000, 275, 21409-21415.

46. Radi, R.; Cassina, A.; Hodara, R. Nitric oxide and peroxynitrite interactions with mitochondria. Biol. Chem. 2002, 383, 401-409. 
47. Takakura, K.; Beckman, J.S.; MacMillan-Crow, L.A.; Crow, J.P. Rapid and irreversible inactivation of protein tyrosine phosphatases ptp1b, cd45, and lar by peroxynitrite. Arch. Biochem. Biophys. 1999, 369, 197-207.

48. Daiber, A.; Frein, D.; Namgaladze, D.; Ullrich, V. Oxidation and nitrosation in the nitrogen monoxide/superoxide system. J. Biol. Chem. 2002, 277, 11882-11888.

49. Pryor, W.A.; Jin, X.; Squadrito, G.L. One- and two-electron oxidations of methionine by peroxynitrite. Proc. Natl. Acad. Sci. USA 1994, 91, 11173-11177.

50. Perrin, D.; Koppenol, W.H. The quantitative oxidation of methionine to methionine sulfoxide by peroxynitrite. Arch. Biochem. Biophys. 2000, 377, 266-272.

51. Pfeiffer, S.; Schmidt, K.; Mayer, B. Dityrosine formation outcompetes tyrosine nitration at low steady-state concentrations of peroxynitrite. Implications for tyrosine modification by nitric oxide/superoxide in vivo. J. Biol. Chem. 2000, 275, 6346-6352.

52. Goldstein, S.; Czapski, G.; Lind, J.; Merenyi, G. Tyrosine nitration by simultaneous generation of ( $\cdot$ )no and $\mathrm{O}-(2)$ under physiological conditions. How the radicals do the job. J. Biol. Chem. 2000, 275, 3031-3036.

53. Pfeiffer, S.; Lass, A.; Schmidt, K.; Mayer, B. Protein tyrosine nitration in cytokine-activated murine macrophages. Involvement of a peroxidase/nitrite pathway rather than peroxynitrite. J. Biol. Chem. 2001, 276, 34051-34058.

54. Schildknecht, S.; Heinz, K.; Daiber, A.; Hamacher, J.; Kavakli, C.; Ullrich, V.; Bachschmid, M. Autocatalytic tyrosine nitration of prostaglandin endoperoxide synthase-2 in lps-stimulated raw 264.7 macrophages. Biochem. Biophys. Res. Commun. 2006, 340, 318-325.

55. Bachschmid, M.; Schildknecht, S.; Ullrich, V. Redox regulation of vascular prostanoid synthesis by the nitric oxide-superoxide system. Biochem. Biophys. Res. Commun. 2005, 338, 536-542.

56. Whiteman, M.; Ketsawatsakul, U.; Halliwell, B. A reassessment of the peroxynitrite scavenging activity of uric acid. Ann. N. Y. Acad. Sci. 2002, 962, 242-259.

57. Robinson, K.M.; Morre, J.T.; Beckman, J.S. Triuret: A novel product of peroxynitrite-mediated oxidation of urate. Arch. Biochem. Biophys. 2004, 423, 213-217.

58. Masumoto, H.; Sies, H. The reaction of ebselen with peroxynitrite. Chem. Res. Toxicol. 1996, 9, 262-267.

59. Daiber, A.; Zou, M.H.; Bachschmid, M.; Ullrich, V. Ebselen as a peroxynitrite scavenger in vitro and ex vivo. Biochem. Pharmacol. 2000, 59, 153-160.

60. 3-morpholinosydnonimine (Sin-1) is the active metabolite of Molsidomin, a nitrovasodilator and cardiovascular drug, which upon hydrolysis undergoes autoxidation by molecular oxygen and thereby generates superoxide anion radicals. The resulting Sin-1 cation radical undergoes fragmentation and yields nitric oxide and Sin-1C. Since the formation of superoxide and nitric oxide is stoichiometric, these radicals almost quantitatively form peroxynitrite in a diffusion controlled reaction. Since the release of peroxynitrite from Sin-1 under physiological conditions is slow, this compound is frequently used to mimic biological fluxes of nitric oxide, superoxide and peroxynitrite.

61. Ferrer-Sueta, G.; Batinic-Haberle, I.; Spasojevic, I.; Fridovich, I.; Radi, R. Catalytic scavenging of peroxynitrite by isomeric mn (iii) $n$-methylpyridylporphyrins in the presence of reductants. Chem. Res. Toxicol. 1999, 12, 442-449. 
62. Crow, J.P. Manganese and iron porphyrins catalyze peroxynitrite decomposition and simultaneously increase nitration and oxidant yield: Implications for their use as peroxynitrite scavengers in vivo. Arch. Biochem. Biophys. 1999, 371, 41-52.

63. Daiber, A.; Mehl, M.; Ullrich, V. New aspects in the reaction mechanism of phenol with peroxynitrite: The role of phenoxy radicals. Nitric Oxide 1998, 2, 259-269.

64. Lymar, S.V.; Khairutdinov, R.F.; Hurst, J.K. Hydroxyl radical formation by O-O bond homolysis in peroxynitrous acid. Inorg. Chem. 2003, 42, 5259-5266.

65. Van der Vliet, A.; O’Neill, C.A.; Halliwell, B.; Cross, C.E.; Kaur, H. Aromatic hydroxylation and nitration of phenylalanine and tyrosine by peroxynitrite. Evidence for hydroxyl radical production from peroxynitrite. FEBS Lett. 1994, 339, 89-92.

66. Ferdinandy, P.; Schulz, R. Inhibition of peroxynitrite-induced dityrosine formation with oxidized and reduced thiols, nitric oxide donors, and purine derivatives. Antioxid. Redox Signal. 2001, 3, $165-171$.

67. Carroll, R.T.; Galatsis, P.; Borosky, S.; Kopec, K.K.; Kumar, V.; Althaus, J.S.; Hall, E.D. 4-hydroxy-2,2,6,6-tetramethylpiperidine-1-oxyl (tempol) inhibits peroxynitrite-mediated phenol nitration. Chem. Res. Toxicol. 2000, 13, 294-300.

68. Crow, J.P.; Beckman, J.S.; McCord, J.M. Sensitivity of the essential zinc-thiolate moiety of yeast alcohol dehydrogenase to hypochlorite and peroxynitrite. Biochemistry 1995, 34, 3544-3552.

69. Kissner, R.; Nauser, T.; Bugnon, P.; Lye, P.G.; Koppenol, W.H. Formation and properties of peroxynitrite as studied by laser flash photolysis, high-pressure stopped-flow technique, and pulse radiolysis. Chem. Res. Toxicol. 1997, 10, 1285-1292.

70. Epe, B.; Ballmaier, D.; Roussyn, I.; Briviba, K.; Sies, H. DNA damage by peroxynitrite characterized with DNA repair enzymes. Nucleic Acids Res. 1996, 24, 4105-4110.

71. Darley-Usmar, V.M.; Hogg, N.; O’Leary, V.J.; Wilson, M.T.; Moncada, S. The simultaneous generation of superoxide and nitric oxide can initiate lipid peroxidation in human low density lipoprotein. Free Radic. Res. Commun. 1992, 17, 9-20.

72. Radi, R.; Beckman, J.S.; Bush, K.M.; Freeman, B.A. Peroxynitrite-induced membrane lipid peroxidation: The cytotoxic potential of superoxide and nitric oxide. Arch. Biochem. Biophys. 1991, 288, 481-487.

73. Rubbo, H.; Radi, R.; Trujillo, M.; Telleri, R.; Kalyanaraman, B.; Barnes, S.; Kirk, M.; Freeman, B.A. Nitric oxide regulation of superoxide and peroxynitrite-dependent lipid peroxidation. Formation of novel nitrogen-containing oxidized lipid derivatives. J. Biol. Chem. 1994, 269, 26066-26075.

74. Moore, K.P.; Darley-Usmar, V.; Morrow, J.; Roberts, L.J., 2nd. Formation of f2-isoprostanes during oxidation of human low-density lipoprotein and plasma by peroxynitrite. Circ. Res. 1995, 77, 335-341.

75. Khor, H.K.; Fisher, M.T.; Schoneich, C. Potential role of methionine sulfoxide in the inactivation of the chaperone groel by hypochlorous acid (HOCl) and peroxynitrite (ONOO-). J. Biol. Chem. 2004, 279, 19486-19493.

76. Sharov, V.S.; Schoneich, C. Diastereoselective protein methionine oxidation by reactive oxygen species and diastereoselective repair by methionine sulfoxide reductase. Free Radic. Biol. Med. 2000, 29, 986-994. 
77. Beckmann, J.S.; Ye, Y.Z.; Anderson, P.G.; Chen, J.; Accavitti, M.A.; Tarpey, M.M.; White, C.R. Extensive nitration of protein tyrosines in human atherosclerosis detected by immunohistochemistry. Biol. Chem. Hoppe Seyler 1994, 375, 81-88.

78. Wayenberg, J.L.; Ransy, V.; Vermeylen, D.; Damis, E.; Bottari, S.P. Nitrated plasma albumin as a marker of nitrative stress and neonatal encephalopathy in perinatal asphyxia. Free Radic. Biol. Med. 2009, 47, 975-982.

79. Wayenberg, J.L.; Cavedon, C.; Ghaddhab, C.; Lefevre, N.; Bottari, S.P. Early transient hypoglycemia is associated with increased albumin nitration in the preterm infant. Neonatology 2011, 100, 387-397.

80. Zou, M.H.; Ullrich, V. Peroxynitrite formed by simultaneous generation of nitric oxide and superoxide selectively inhibits bovine aortic prostacyclin synthase. FEBS Lett. 1996, 382, 101-104.

81. Kozak, A.J.; Liu, F.; Funovics, P.; Jacoby, A.; Kubant, R.; Malinski, T. Role of peroxynitrite in the process of vascular tone regulation by nitric oxide and prostanoids-A nanotechnological approach. Prostaglandins Leukot. Essent. Fatty Acids 2005, 72, 105-113.

82. Zou, M.H.; Klein, T.; Pasquet, J.P.; Ullrich, V. Interleukin 1beta decreases prostacyclin synthase activity in rat mesangial cells via endogenous peroxynitrite formation. Biochem. J. 1998, 336, 507-512.

83. Spisni, E.; Griffoni, C.; Santi, S.; Riccio, M.; Marulli, R.; Bartolini, G.; Toni, M.; Ullrich, V.; Tomasi, V. Colocalization prostacyclin (pgi2) synthase-Caveolin-1 in endothelial cells and new roles for pgi2 in angiogenesis. Exp. Cell Res. 2001, 266, 31-43.

84. Bachschmid, M.; Ullrich, V. Redox signalling in endothelial cells-Novel mechanisms explaining endothelium function and dysfunction in health, disease and aging. B.I.F. FUTURA 2003, 18, 223-230.

85. Schildknecht, S.; Bachschmid, M.; Ullrich, V. Peroxynitrite provides the peroxide tone for pghs-2-dependent prostacyclin synthesis in vascular smooth muscle cells. FASEB J. 2005, 19, 1169-1171.

86. Drelicharz, L.; Kozlovski, V.; Skorka, T.; Heinze-Paluchowska, S.; Jasinski, A.; Gebska, A.; Guzik, T.; Olszanecki, R.; Wojnar, L.; Mende, U.; et al. No and pgi(2) in coronary endothelial dysfunction in transgenic mice with dilated cardiomyopathy. Basic Res. Cardiol. 2008, 103, 417-430.

87. Lorkowska, B.; Bartus, M.; Franczyk, M.; Kostogrys, R.B.; Jawien, J.; Pisulewski, P.M.; Chlopicki, S. Hypercholesterolemia does not alter endothelial function in spontaneously hypertensive rats. J. Pharmacol. Exp. Ther. 2006, 317, 1019-1026.

88. Koppenol, W.H.; Moreno, J.J.; Pryor, W.A.; Ischiropoulos, H.; Beckman, J.S. Peroxynitrite, a cloaked oxidant formed by nitric oxide and superoxide. Chem. Res. Toxicol. 1992, 5, 834-842.

89. Pfeiffer, S.; Gorren, A.C.; Schmidt, K.; Werner, E.R.; Hansert, B.; Bohle, D.S.; Mayer, B. Metabolic fate of peroxynitrite in aqueous solution. Reaction with nitric oxide and ph-dependent decomposition to nitrite and oxygen in a 2:1 stoichiometry. J. Biol. Chem. 1997, 272, 3465-3470.

90. Ketsawatsakul, U.; Whiteman, M.; Halliwell, B. A reevaluation of the peroxynitrite scavenging activity of some dietary phenolics. Biochem. Biophys. Res. Commun. 2000, 279, 692-699. 
91. Arteel, G.E.; Briviba, K.; Sies, H. Protection against peroxynitrite. FEBS Lett. 1999, 445, 226-230.

92. Kaur, I.P.; Geetha, T. Screening methods for antioxidants-A review. Mini Rev. Med. Chem. 2006, 6, 305-312.

93. Merenyi, G.; Lind, J.; Goldstein, S. The rate of homolysis of adducts of peroxynitrite to the $\mathrm{C}=\mathrm{O}$ double bond. J. Am. Chem. Soc. 2002, 124, 40-48.

94. Sawa, T.; Akaike, T.; Maeda, H. Tyrosine nitration by peroxynitrite formed from nitric oxide and superoxide generated by xanthine oxidase. J. Biol. Chem. 2000, 275, 32467-32474.

95. Boddupalli, S.S.; Estabrook, R.W.; Peterson, J.A. Fatty acid monooxygenation by cytochrome p-450bm-3. J. Biol. Chem. 1990, 265, 4233-4239.

96. Graham-Lorence, S.; Truan, G.; Peterson, J.A.; Falck, J.R.; Wei, S.; Helvig, C.; Capdevila, J.H. An active site substitution, $f 87 \mathrm{v}$, converts cytochrome p450 bm-3 into a regio- and stereoselective $(14 s, 15 r)$-arachidonic acid epoxygenase. J. Biol. Chem. 1997, 272, 1127-1135.

97. Jung, C.; Hoa, G.H.; Schroder, K.L.; Simon, M.; Doucet, J.P. Substrate analogue induced changes of the co-stretching mode in the cytochrome p450cam-carbon monoxide complex. Biochemistry 1992, 31, 12855-12862.

98. Nakahara, K.; Tanimoto, T.; Hatano, K.; Usuda, K.; Shoun, H. Cytochrome p-450 55a1 (p-450dnir) acts as nitric oxide reductase employing nadh as the direct electron donor. J. Biol. Chem. 1993, 268, 8350-8355.

99. Wada, M.; Yokoyama, C.; Hatae, T.; Shimonishi, M.; Nakamura, M.; Imai, Y.; Ullrich, V.; Tanabe, T. Purification and characterization of recombinant human prostacyclin synthase. J. Biochem. 2004, 135, 455-463.

100. Lee, D.S.; Nioche, P.; Hamberg, M.; Raman, C.S. Structural insights into the evolutionary paths of oxylipin biosynthetic enzymes. Nature 2008, 455, 363-368.

101. Schuhmacher, S.; Oelze, M.; Bollmann, F.; Kleinert, H.; Otto, C.; Heeren, T.; Steven, S.; Hausding, M.; Knorr, M.; Pautz, A.; et al. Vascular dysfunction in experimental diabetes is improved by pentaerithrityl tetranitrate but not isosorbide-5-mononitrate therapy. Diabetes 2011, 60, 2608-2616.

102. Oelze, M.; Knorr, M.; Schuhmacher, S.; Heeren, T.; Otto, C.; Schulz, E.; Reifenberg, K.; Wenzel, P.; Munzel, T.; Daiber, A. Vascular dysfunction in streptozotocin-induced experimental diabetes strictly depends on insulin deficiency. J. Vasc. Res. 2011, 48, 275-284.

103. Siegle, I.; Nusing, R.; Brugger, R.; Sprenger, R.; Zecher, R.; Ullrich, V. Characterization of monoclonal antibodies generated against bovine and porcine prostacyclin synthase and quantitation of bovine prostacyclin synthase. FEBS Lett. 1994, 347, 221-225.

104. Nathans, G.R.; Hade, E.P. Proteolytic activity in bovine milk xanthine oxidase preparations. Biochem. Biophys. Res. Commun. 1975, 66, 108-114.

105. Zou, M.H.; Shi, C.; Cohen, R.A. High glucose via peroxynitrite causes tyrosine nitration and inactivation of prostacyclin synthase that is associated with thromboxane/prostaglandin $\mathrm{h}(2)$ receptor-mediated apoptosis and adhesion molecule expression in cultured human aortic endothelial cells. Diabetes 2002, 51, 198-203.

106. Zou, M.H.; Leist, M.; Ullrich, V. Selective nitration of prostacyclin synthase and defective vasorelaxation in atherosclerotic bovine coronary arteries. Am. J. Pathol. 1999, 154, 1359-1365. 
107. Zou, M.H.; Bachschmid, M. Hypoxia-reoxygenation triggers coronary vasospasm in isolated bovine coronary arteries via tyrosine nitration of prostacyclin synthase. J. Exp. Med. 1999, 190, $135-139$.

108. Hink, U.; Oelze, M.; Kolb, P.; Bachschmid, M.; Zou, M.H.; Daiber, A.; Mollnau, H.; August, M.; Baldus, S.; Tsilimingas, N.; et al. Role for peroxynitrite in the inhibition of prostacyclin synthase in nitrate tolerance. J. Am. Coll. Cardiol. 2003, 42, 1826-1834.

109. Bachschmid, M.; Thurau, S.; Zou, M.H.; Ullrich, V. Endothelial cell activation by endotoxin involves superoxide/no-mediated nitration of prostacyclin synthase and thromboxane receptor stimulation. FASEB J. 2003, 17, 914-916.

(C) 2013 by the authors; licensee MDPI, Basel, Switzerland. This article is an open access article distributed under the terms and conditions of the Creative Commons Attribution license (http://creativecommons.org/licenses/by/3.0/). 